\title{
Community structure of benthic macroinvertebrates inhabiting a highly stratified Mediterranean estuary
}

\author{
ALFONSO NEBRA, NUNO CAIOLA and CARLES IBÁÑEZ \\ IRTA Aquatic Ecosystems, Ctra. de Poble Nou, km 5.5, E-43540, Sant Carles de la Ràpita, Tarragona, Spain. \\ E-mail: nuno.caiola@irta.cat
}

SUMMARY: The community composition and spatial distribution of benthic macroinvertebrates were studied along the Ebro estuary, a highly stratified estuary located in the NE Iberian Peninsula. During the last decade the oligotrophication process occurring in the lower Ebro River and its estuary has allowed a complex benthic macroinvertebrate community to become established; these results contrast with the poor community found there in the early nineties. A total of 214 taxa were identified, and polychaetes dominated the community both in abundance and species richness. The results showed spatial differences in the structure and composition of macroinvertebrates, which suggests that there are two distinct communities along the estuary. Each community was found in a specific stretch (upper and lower estuary) in function of the presence of the salt wedge. The macrobenthos of the upper estuary was dominated by freshwater taxa, but some euryhaline species were also found. The lower estuary showed a marine community typical of shallow Mediterranean environments. The transition between these two communities fits an ecotone model. The highest abundances, richness and diversities were recorded at the lower estuarine stations, especially those closer to the river mouth, whereas the lowest values corresponded to the stations adjacent to the tip of the salt wedge.

Keywords: benthic macroinvertebrates, community structure, distribution patterns, salt wedge, highly stratified estuary, Ebro estuary.

RESUMEN: ESTRUCTURA DE LA COMUNIDAD DE MACROINVERTEBRADOS BENTÓNICOS EN UN ESTUARIO MEDITERRÁNEO ALTAMENTE ESTRATIFICADO. - La composición de la comunidad y la distribución espacial de los macroinvertebrados bentónicos ha sido estudiada a lo largo del estuario del Río Ebro, un estuario altamente estratificado localizado al NE de la Península Ibérica. El proceso de oligotrofización ocurrido durante la última década en el tramo bajo del río Ebro y su estuario, ha permitido el establecimiento de una compleja comunidad de macroinvertebrados, contrastando con la comunidad encontrada a principios de los noventa. Un total de 214 taxones fueron identificados; los poliquetos constituyeron el grupo dominante en términos de riqueza y abundancia. Los resultados mostraron diferencias espaciales en la estructura y composición de macroinvertebrados, sugiriendo la existencia de dos comunidades diferentes a lo largo del estuario. Cada una de estas comunidades fue encontrada en un tramo específico (alto y bajo estuario) en función de la presencia de la cuña salina. El macrobentos del tramo alto del estuario estaba integrado mayoritariamente por taxones de agua dulce y algunos taxones eurihalinos. Por el contario, el tramo bajo presentó una comunidad marina típica de ambientes mediterráneos someros. La transición entre estas dos comunidades encajó con un modelo ecotonal. Las abundancias, riquezas y diversidades más elevadas fueron registradas en las estaciones del tramo bajo, especialmente en aquellas cercanas a la desembocadura; en cambio, los valores más bajos correspondieron a las estaciones adyacentes al extremo de la cuña salina.

Palabras clave: macroinvertebrados bentónicos, estructura de la comunidad, patrones de distribución, cuña salina, estuario altamente estratificado, estuario del Ebro.

\section{INTRODUCTION}

The Ebro estuary (NE, Iberian Peninsula) is a salt wedge or highly stratified estuary (Hansen and Rattray, 1966; Ibáñez et al., 1997). The specific characteristics of salt wedge estuaries are: (i) the river discharge controls the marine intrusion mainly due to the low tidal range (usually with an amplitude less than 2 meters); (ii) weak mixing effects cause the water column to be strongly stratified; (iii) the vertical profile of density 
and salinity shows a marked change with a narrow interface between layers called haloclines; and (iv) the isohalines are arranged horizontally. Although this kind of estuary is well represented along microtidal coasts worldwide (e.g. the Mediterranean Sea and the Gulf of Mexico), there is little research on the macroinvertebrate communities that inhabit them. The Ebro estuary has been extensively studied in relation to its hydrology and salt wedge dynamics (e.g. Ibáñez et al., 1997, 1999; Sierra et al., 2002, 2004), and some benthic communities of adjacent areas have also been studied (Capaccioni-Azzati and Martín, 1992; Martín et al., 2000). A few studies have focused on the biota of the estuary (e.g. Rovira et al., 2009), but only one includes a brief description of its macroinvertebrate community (Ibáñez et al., 1995). Furthermore, this study was performed when the lower Ebro River and its estuary were under severe eutrophic conditions, very different from the present situation. Highly fluctuating estuarine systems produce strong environmental gradients, which leads to a patchy distribution of organisms that must cope with a wide variety of stresses (Morrisey et al., 1992; Gray and Elliott, 2009) due to both natural and anthropogenic factors (McLusky, 1999; Dauer et al., 2000; Dauvin, 2007; Elliott and Quintino, 2007). Therefore, the benthic invertebrate communities, often used as indicators of the health of an ecosystem, can be very similar in both impacted and non-disturbed estuarine systems. This therefore increases the difficulty of distinguishing natural from anthropogenic stresses. The Estuarine Quality Paradox concept (Dauvin, 2007; Elliott and Quintino, 2007) refers to the challenge of detecting anthropogenic impacts in naturally stressed systems using biological assessment methods. In Mediterranean regions and particularly in the Iberian Peninsula, besides the spatial fluctuation there is strong temporal environmental variability in the aquatic systems due to limited water availability during part of the year (Caiola et al., 2001; Ferreira et al., 2007a). This variability is exacerbated by a long history of human-induced pressures that have led to serious changes in the natural ecological cycles of estuarine systems from this region (Ferreira et al., $2007 b$ ). Therefore, identifying the factors that structure the benthic macroinvertebrate community of the Ebro estuary will provide a clearer understanding of the ecological functioning of the system both at the spatial and temporal scales. Moreover, it will help to interpret the recent changes in the estuarine system observed during the last two decades (Ibáñez et al., 2008). Therefore, this study establishes a robust basis so that macroinvertebrates can be used as indicators of the ecological status of the Ebro estuary.

The purpose of this study was to examine the macroinvertebrate community of the Ebro estuary with regard to species composition, community structure and distribution patterns along spatial and temporal scales and to describe the main abiotic factors affecting benthic communities in this type of estuary.

\section{MATERIALS AND METHODS}

\section{Study area}

The study was conducted in the Ebro estuary (40'43'10' 'N, 0'40'30' $\mathrm{E}$ ) located in the $\mathrm{NE}$ of the Iberian Peninsula (Catalonia, Spain) (Fig.1). The Ebro is $910 \mathrm{~km}$ long and has a drainage area of $85362 \mathrm{~km}^{2}$; it is the Spanish river with the highest mean annual flow and one of the most important tributaries to the Mediterranean Sea. The main land use in the basin is agriculture with more than $10000 \mathrm{~km}^{2}$ of irrigation, corresponding to approximately $90 \%$ of the water usage in the basin (Ibáñez et al., 2008). The whole basin is strongly regulated by nearly 190 dams (Batalla et al., 2004). These affect the mean annual flow, which has decreased greatly since the beginning of the century to the present (Ibáñez et al., 1996). The Ebro estuary is highly stratified (30 km long, $240 \mathrm{~m}$ mean width and 6-8 m mean depth) and the microtidal amplitude of the Mediterranean Sea, about $20 \mathrm{~cm}$ (Cacchione et al., 1990), promotes the formation of a salt wedge. The river discharge controls the salt wedge dynamic (advance, retreat and permanence): when the flow exceeds $350-400 \mathrm{~m}^{3} \mathrm{~s}^{-1}$ the salt wedge is pushed from the river channel, and the salt wedge reaches its maximum distance upstream (30-32 km from the river mouth) with flows lower than $100 \mathrm{~m}^{3} \mathrm{~s}^{-1}$ (Ibáñez et al., 1997).

\section{Sampling design and laboratory procedures}

Nine sampling stations were established in order to cover the whole estuarine stretch of the Ebro River (Fig. 1). Each station was sampled seasonally (summer 2007 to spring 2008). On each sampling occasion, three sediment samples were collected using a Ponar grab $\left(0.046 \mathrm{~m}^{2}\right)$. The samples were washed in situ through a $0.5-\mathrm{mm}$ mesh sieve to separate macroinvertebrates from sediment, and the organisms retained were immediately fixed with buffered $10 \%$ formalin. Later in the laboratory, all macroinvertebrates were sorted, counted and identified under a stereomicroscope to the lowest possible taxonomic level. Two sediment aliquots of $30 \mathrm{~g}$ and $200 \mathrm{~g}$ were taken from each grab and stored at $-20^{\circ} \mathrm{C}$ to estimate the total organic matter (TOM) with the loss on ignition method following Kristensen and Andersen (1987), and grain-size characterization according to Holme and McIntyre (1984). Bottom water samples were collected at each station with a water pump, preserved on ice in the absence of light, transported to the laboratory and stored at $-20^{\circ} \mathrm{C}$ until analysis. Posterior processing included estimating the total chlorophyll and pheophytin concentration using the colorimetric method (Jeffrey and Humphrey, 1975), the dissolved and total nutrient concentration $\left(\mathrm{PO}_{4}, \mathrm{P}_{\mathrm{T}}, \mathrm{NH}_{4}, \mathrm{NO}_{2}, \mathrm{NO}_{3}, \mathrm{~N}_{\mathrm{T}}\right.$ and $\mathrm{SiO}_{4}$ ) following Koroleff (1977) and the suspended solid concentration (Total suspended solids (TSS, $\mathrm{mg} \mathrm{l}^{-1}$ ) and organic suspended solids (OSS, $\left.\mathrm{mg} \mathrm{l}^{-1}\right)$ ) in compliance with the UNE-EN 872 norm (AENOR, 1996). In addi- 


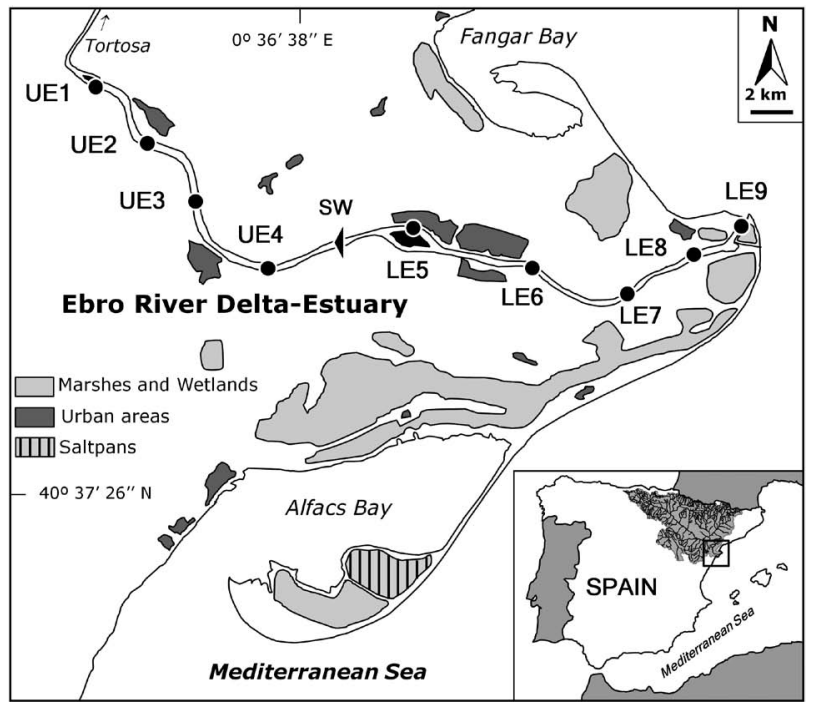

FIG. 1. - Location of the Ebro estuary and its deltaic plain showing the nine sampling stations. UE, upper estuary stations; LE, lower estuary stations; SW, position of the salt wedge tip.

tion, physicochemical and hydromorphological characteristics were recorded on each sampling occasion. A YSI 556 multi-parameter probe was used to measure water temperature $\left({ }^{\circ} \mathrm{C}\right)$, dissolved oxygen $\left(\mathrm{mg} \mathrm{l}^{-1}\right)$, oxygen saturation $(\%), \mathrm{pH}$, salinity and conductivity $(\mathrm{mS}$ $\left.\mathrm{cm}^{-1}\right)$. Water depth $(\mathrm{m})$ was measured using a Speedtech SM-5 depth-meter sounder. Water flow velocity $\left(\mathrm{m} \mathrm{s}^{-1}\right)$ was recorded with a Valeport m.001 current-meter, and water transparency was estimated using a Secchi disc. The accumulated permanence time (in days) of the salt wedge was calculated using daily mean flow values measured $40 \mathrm{~km}$ upstream from the river mouth (Tortosa) by counting the accumulated days before each sampling occasion with mean flow values lower than 350 $\mathrm{m}^{3} \mathrm{~s}^{-1}$. This data is available at the Ebro Water Authority (CHE) web site (http://www.chebro.es/).

\section{Data analysis}

The following community descriptive parameters were calculated for each station and season $(n=36)$ : total abundance $(\mathrm{N})$, density $\left(\mathrm{D}\right.$, ind $\left.\mathrm{m}^{-2}\right)$, richness $(\mathrm{S})$, Shannon-Wiener's diversity index (H', as $\left.\log _{2}\right)$, Margalef index (d), Simpson dominance index $\left(1-\lambda^{\prime}\right)$ and Pielou's evenness index ( $\left.\mathrm{J}^{\prime}\right)$. In addition, species were classified with the constancy index (Dajoz, 1971) into five categories according to the number of stations in which any given taxa was found in relation to the total number of stations: constant $(>76 \%)$, very common (51-75\%), common (26-50\%), uncommon (13-25\%) and rare $(<12 \%)$. Each species was classified into feeding guilds based on the available literature. The feeding guilds included deposit feeders (DF), grazers $(\mathrm{G})$, omnivores $(\mathrm{O})$, parasites $(\mathrm{Pa})$, predators $(\mathrm{Pr})$ and suspension feeders (SF). Appendix 1 provides a list of the taxa, together with their feeding guild, that are mentioned in the text. Non-parametric multivari- ate techniques were used as described by Field et al. (1982) to indentify the possible macroinvertebrate communities. A similarity matrix was computed using the Bray-Curtis coefficient (Legendre and Legendre, 1998) after the four root transformation was applied to the abundance data to downweight the contribution of the most abundant taxa to the similarity (Clarke and Warwick, 2001). All the other statistical analyses were performed using the different routines available in the Multivariate Ecological Research software package PRIMER V6 (Clarke and Gorley, 2006). The stations and taxa were ordered using non-metrical multidimensional scaling (MDS) (Clarke and Warwick, 2001). A similarity percentage analysis (SIMPER) that examines the contribution of each variable to the average resemblances between sample groups was performed. This analysis was also used to identify taxa that contributed to dissimilarity among stations and estuary domains that were pre-determined by ordination analysis. Differences in the community composition were identified using the 1-way analysis of similarities test (ANOSIM) that hypothesizes for differences between groups of samples (defined a priori) through randomization methods on a resemblance matrix. Finally, the relationship between the community structure and environmental variables was investigated with the BIOENV routine, which maximizes a rank correlation (Spearman's coefficient) between resemblance matrices derived from biotic and environmental data, iterating for all possible combinations of environmental variables (Clarke and Warwick, 2001). A Spearman's coefficient value close to 0 indicates a weak relation between the community and environmental variables, whereas a value close to 1 indicates that the environmental variables selected explain the community structure.

\section{RESULTS}

\section{Water and sediment features}

The Ebro estuary has a sand dominated bottom and a relatively low TOM percentage in both the upper (UE) and lower (LE) parts and throughout the entire year (Table 1). During the study period the salt wedge was only found in the lower estuary stations. At these stations, the accumulated permanence time was different in each season: 55, 143, 257 and 344 days respectively for summer, autumn, winter and spring. The null point (the tip of the salt wedge) was located between UE4 and LE5 in all sampling periods. Nutrient concentrations were higher in the upper estuary stretch (Table 1) except for the ammonia, nitrite, phosphate and silicate concentrations in spring and total phosphorous in summer. The chlorophyll concentrations showed marked differences between the upper and lower estuary; the UE stretch had the highest values during winter and spring, whereas the maximum values in the LE stretch were in summer/autumn. Levels of total pheophytin were lower in the UE stretch except for during the two 
TABLE 1. - Sediment characteristics and water physicochemical parameters (seasonal mean \pm standard deviation, $\mathrm{n}=4$ ) in the two different stretches. TOM, total organic matter in sediment; Transp., transparency; DO, dissolved oxygen; Cond., conductivity; Sal., salinity; TDS, total dissolved salts; TSS, total suspended solids; OSS, organic suspended solids.

\begin{tabular}{|c|c|c|c|c|c|c|c|c|}
\hline & \multicolumn{4}{|c|}{ Upper Estuary } & \multicolumn{4}{|c|}{ Lower Estuary } \\
\hline & Summer & Autumn & Winter & Spring & Summer & Autumn & Winter & Spring \\
\hline Iud (\%) & $11.31 \pm 14.59$ & $11.31 \pm 14.59$ & $21.08 \pm 28.43$ & $1.53 \pm 2.08$ & $15.89 \pm 10.90$ & $15.89 \pm 10.90$ & $25.27 \pm 20.78$ & $6.51 \pm 5.75$ \\
\hline Sand $(\%)$ & $73.35 \pm 23.41$ & $73.35 \pm 23.41$ & $57.93 \pm 33.30$ & $88.78 \pm 16.81$ & $79.84 \pm 13.01$ & $79.84 \pm 13.01$ & $74.32 \pm 21.06$ & $85.36 \pm 18.10$ \\
\hline Gravel (\%) & $15.34 \pm 27.22$ & $15.34 \pm 27.22$ & $20.99 \pm 36.79$ & $9.69 \pm 17.68$ & $4.27 \pm 6.26$ & $4.27 \pm 6.26$ & $0.41 \pm 0.29$ & $8.13 \pm 12.52$ \\
\hline TOM $(\%)$ & $2.67 \pm 1.03$ & $2.67 \pm 1.03$ & $2.89 \pm 1.11$ & $2.45 \pm 1.88$ & $4.03 \pm 1.22$ & $4.03 \pm 1.22$ & $4.36 \pm 1.59$ & $3.70 \pm 2.21$ \\
\hline Depth (m) & $3.50 \pm 1.73$ & $4.25 \pm 1.89$ & $3.75 \pm 2.22$ & $4.25 \pm 2.06$ & $6.00 \pm 1.41$ & $6.80 \pm 1.48$ & $6.00 \pm 1.58$ & $6.00 \pm 1.58$ \\
\hline Velocity $\left(\mathrm{m} \mathrm{s}^{-1}\right)$ & $0.13 \pm 0.06$ & $0.17 \pm 0.05$ & $0.14 \pm 0.05$ & $0.42 \pm 0.10$ & $0.06 \pm 0.04$ & $0.10 \pm 0.09$ & $0.05 \pm 0.05$ & $0.25 \pm 0.21$ \\
\hline Transp. (m) & $2.40 \pm 0.71$ & $2.68 \pm 0.78$ & $1.98 \pm 0.73$ & $2.21 \pm 0.22$ & $2.37 \pm 0.27$ & $1.89 \pm 0.23$ & $1.88 \pm 0.13$ & $1.60 \pm 0.22$ \\
\hline $\mathrm{T}\left({ }^{\circ} \mathrm{C}\right)$ & $24.26 \pm 0.40$ & $22.80 \pm 0.07$ & $11.12 \pm 0.36$ & $16.32 \pm 0.14$ & $22.07 \pm 0.19$ & $22.30 \pm 0.83$ & $13.27 \pm 0.04$ & $15.30 \pm 0.51$ \\
\hline $\mathrm{DO}\left(\mathrm{mg} \mathrm{l}^{-1}\right)$ & $7.85 \pm 0.47$ & $7.89 \pm 1.22$ & $13.82 \pm 0.69$ & $7.94 \pm 0.69$ & $5.25 \pm 1.22$ & $6.00 \pm 2.4$ & $10.32 \pm 0.83$ & $6.72 \pm 2.11$ \\
\hline DO $(\%)$ & $94.00 \pm 6.26$ & $92.00 \pm 14.25$ & $126.28 \pm 7.02$ & $81.30 \pm 7.24$ & $74.10 \pm 17.64$ & $84.78 \pm 33.61$ & $123.90 \pm 10.11$ & $74.36 \pm 16.52$ \\
\hline Cond. $\left(\mathrm{mS} \mathrm{cm}^{-1}\right)$ & $0.95 \pm 0.01$ & $1.37 \pm 0.00$ & $1.12 \pm 0.03$ & $1.04 \pm 0.00$ & $51.27 \pm 0.53$ & $51.51 \pm 0.71$ & $43.21 \pm 0.50$ & $25.00 \pm 19.78$ \\
\hline Sal. & $0.47 \pm 0.01$ & $0.72 \pm 0.00$ & $0.77 \pm 0.02$ & $0.62 \pm 0.00$ & $35.97 \pm 0.31$ & $35.98 \pm 0.40$ & $36.89 \pm 0.45$ & $20.02 \pm 16.27$ \\
\hline $\operatorname{TDS}\left(\mathrm{g} \mathrm{l}^{-1}\right)$ & $0.62 \pm 0.01$ & $0.93 \pm 0.00$ & $0.99 \pm 0.02$ & $0.81 \pm 0.00$ & $35.30 \pm 0.27$ & $35.30 \pm 0.34$ & $36.19 \pm 0.39$ & $20.09 \pm 15.95$ \\
\hline Chlorophyll $\left(\mu \mathrm{g} \mathrm{l}^{-1}\right)$ & $0.09 \pm 0.06$ & $1.16 \pm 0.24$ & $1.07 \pm 0.91$ & $2.83 \pm 2.82$ & $1.01 \pm 0.80$ & $2.83 \pm 1.06$ & $0.79 \pm 0.23$ & $0.69 \pm 0.41$ \\
\hline Pheophytin ( $\left.\mu \mathrm{g} \mathrm{l}^{-1}\right)$ & $0.05 \pm 0.02$ & $1.06 \pm 0.10$ & $1.00 \pm 0.55$ & $3.43 \pm 2.28$ & $0.31 \pm 0.18$ & $1.38 \pm 0.32$ & $0.66 \pm 0.26$ & $0.87 \pm 0.50$ \\
\hline $\mathrm{pH}$ & $8.20 \pm 0.06$ & $8.25 \pm 0.05$ & $7.89 \pm 0.09$ & $8.00 \pm 0.02$ & $7.98 \pm 0.06$ & $8.28 \pm 0.15$ & $7.94 \pm 0.05$ & $7.83 \pm 0.11$ \\
\hline PO4 $\left(\mathrm{mg} \mathrm{l}^{-1}\right)$ & $0.02 \pm 0.00$ & $0.03 \pm 0.00$ & $0.03 \pm 0.01$ & $0.03 \pm 0.01$ & $0.01 \pm 0.01$ & $0.01 \pm 0.02$ & $0.01 \pm 0.01$ & $0.03 \pm 0.01$ \\
\hline $\mathrm{P}_{\mathrm{T}}\left(\mathrm{mg} \mathrm{l}^{-1}\right)$ & $0.08 \pm 0.01$ & $0.06 \pm 0.01$ & $0.05 \pm 0.01$ & $0.05 \pm 0.00$ & $0.11 \pm 0.02$ & $0.05 \pm 0.02$ & $0.02 \pm 0.02$ & $0.04 \pm 0.02$ \\
\hline $\mathrm{NH}_{4}\left(\mathrm{mg} \mathrm{l}^{-1}\right)$ & $0.02 \pm 0.02$ & $0.04 \pm 0.03$ & $0.02 \pm 0.02$ & $0.19 \pm 0.14$ & $0.05 \pm 0.02$ & $0.09 \pm 0.12$ & $0.05 \pm 0.02$ & $0.20 \pm 0.30$ \\
\hline $\mathrm{NO}_{2}\left(\mathrm{mg} \mathrm{l}^{-1}\right)$ & $0.01 \pm 0.00$ & $0.01 \pm 0.00$ & $0.02 \pm 0.00$ & $0.04 \pm 0.01$ & $0.00 \pm 0.01$ & $0.00 \pm 0.01$ & $0.01 \pm 0.00$ & $0.04 \pm 0.01$ \\
\hline $\mathrm{NO}_{3}\left(\mathrm{mg} \mathrm{l}^{-1}\right)$ & $2.08 \pm 0.16$ & $1.85 \pm 0.34$ & $3.52 \pm 0.05$ & $4.45 \pm 0.15$ & $0.04 \pm 0.03$ & $0.04 \pm 0.02$ & $0.10 \pm 0.02$ & $3.26 \pm 0.89$ \\
\hline $\mathrm{N}_{\mathrm{T}}\left(\mathrm{mg} \mathrm{l}^{-1}\right)$ & $2.42 \pm 0.08$ & $2.43 \pm 0.04$ & $3.52 \pm 0.05$ & $5.37 \pm 0.08$ & $0.28 \pm 0.07$ & $0.20 \pm 0.12$ & $0.10 \pm 0.02$ & $4.39 \pm 1.13$ \\
\hline $\mathrm{SiO}_{4}\left(\mathrm{mg} \mathrm{l}^{-1}\right)$ & $1.89 \pm 0.06$ & $0.85 \pm 0.17$ & $1.01 \pm 0.15$ & $1.21 \pm 0.13$ & $0.42 \pm 0.48$ & $0.47 \pm 0.33$ & $0.17 \pm 0.16$ & $1.28 \pm 0.31$ \\
\hline $\operatorname{TSS}\left(\mathrm{mg} \mathrm{l}^{-1}\right)$ & $3.05 \pm 0.98$ & $3.56 \pm 2.68$ & $2.91 \pm 1.66$ & $14.69 \pm 11.25$ & $20.60 \pm 2.17$ & $24.99 \pm 3.78$ & $16.91 \pm 32.53$ & $5.84 \pm 3.51$ \\
\hline OSS $\left(\mathrm{mg} \mathrm{l}^{-1}\right)$ & $1.94 \pm 0.52$ & $1.47 \pm 0.81$ & $0.99 \pm 0.21$ & $3.20 \pm 2.31$ & $4.75 \pm 1.11$ & $4.71 \pm 1.02$ & $1.76 \pm 2.27$ & $1.52 \pm 0.75$ \\
\hline OSS (\%) & $66.49 \pm 18.14$ & $46.07 \pm 8.76$ & $43.07 \pm 21.78$ & $23.19 \pm 2.59$ & $22.92 \pm 3.70$ & $18.72 \pm 1.53$ & $27.34 \pm 12.39$ & $27.04 \pm 2.95$ \\
\hline
\end{tabular}

last seasons. The UE stretch always had seasonal mean water flow velocities higher than the LE stretch. The values of TSS and OSS were higher in the LE stretch in summer, autumn and winter, whereas in spring the UE stretch showed the maximum values.

\section{Macroinvertebrate abundance, taxa richness and diversity}

During one year of seasonal sampling in the Ebro estuary a total of 21805 individuals were collected belonging to 214 different taxa that comprised 151 species, 115 families, 57 orders, 20 classes and 9 phyla (Supplementary material Appendix 1). Annelida was the dominant phylum and accounted for $71.07 \%$ of the total abundance. Polychaeta and Oligochaeta contributed with $49.64 \%$ and $21.42 \%$ respectively. Spionidae was the most abundant family $(28.56 \%)$ due to the contribution of the most dominant species Streblospio benedicti ( $24.10 \%$ of the total abundance). Another dominant phylum was Arthropoda, which contributed $15.56 \%$ of the total abundance, with Malacostraca accounting for $10.37 \%$ of the total abundance. Mollusca was the third most abundant phylum with $12.09 \%$ of the total abundance, and Bivalvia contributed $10.61 \%$ of the total abundance. In terms of species richness, Polychaeta contributed with 49 different taxa (40 species) and Bivalvia with 37 taxa (32 sp), followed by Gastropoda with 29 taxa (18 sp) and Euentomata with 24 taxa (14 sp). Applying Dajoz's constancy index (considering the 9 stations), $1 \%$ of the taxa were found constant, $8 \%$ very common, $27 \%$ common, $20 \%$ uncommon and $44 \%$ were rare. Applying the constancy index to UE stations revealed that $9 \%$ of the taxa were constant, $14 \%$ very common, $19 \%$ common, $58 \%$ were uncommon and no taxa were rare; whereas in the LE stretch $22 \%$ of the taxa were constant, $16 \%$ very common, $20 \%$ common and $42 \%$ were uncommon.

Total density values throughout seasons ranged from 216 to 20022 ind $\mathrm{m}^{-2}$ (Table 2). The highest densities were found at the mouth (station LE9) due to the high abundance of the polychaete $S$. benedicti. Intermediate densities were found in the uppermost stations UE1 and UE2 with a large contribution of Tubificidae and the introduced bivalve Corbicula fluminea. The lowest densities corresponded to stations UE3, UE4 and LE5 in the middle part of the estuary. Station LE9 had the highest richness values with a maximum of 69 taxa and an annual mean value of 48 taxa; other stations located near the river mouth (LE8 and LE7) also reached high values of richness, whereas stations UE3, UE4 and LE5 showed the lowest richness values (Table 2). Diversity indices showed the same tendency as density and richness, with low values at stations located near the limit of the salt wedge (Table 2). In terms of the trophic structure, the deposit feeders $(32 \%)$, suspension feeders (29\%) and predators (17\%) were the dominant feeding guilds in the entire estuary. The contribution of the different feeding guilds in the UE stretch was: deposit feeders $(38 \%)$, predators $(22 \%)$, grazers $(19 \%)$, suspension feeders $(14 \%)$, omnivores $(5 \%)$ and parasites $(3 \%)$. The trophic structure of the LE stretch was dominated by suspension feeders (35\%) and deposit feeders $(30 \%)$. 
TABLE 2. - Community descriptive parameters for each sampling station and season. N, total abundance per $0.14 \mathrm{~m}^{2} ; \mathrm{D}$, density (ind $\mathrm{m}^{-2}$ ); $\mathrm{S}$, richness; H'( $\left.\log _{2}\right)$, Shannon-Wiener diversity index; d, Margalef index; 1- $\lambda$ ', Simpson's index; J', Pielou's evenness; DF (\%), deposit feeders; $\mathrm{G}(\%)$, grazers; O (\%), omnivores; Pa (\%), parasites; Pr (\%), predators; SF (\%), suspension feeders. See Figure 1 for sampling station codes.

\begin{tabular}{|c|c|c|c|c|c|c|c|c|c|c|c|c|c|}
\hline \multirow[t]{2}{*}{ Station } & \multirow[t]{2}{*}{ Season } & \multirow[t]{2}{*}{ Density } & \multicolumn{5}{|c|}{ Community indices } & \multicolumn{6}{|c|}{ Trophic structure } \\
\hline & & & $\mathrm{S}$ & $H^{\prime}\left(\log _{2}\right)$ & d & $1-\lambda$ & $\mathrm{J}^{\prime}$ & DF & $\mathrm{G}$ & $\mathrm{O}$ & $\mathrm{Pa}$ & $\operatorname{Pr}$ & SF \\
\hline UE1 & Summer & 2792 & 11 & 1.96 & 1.68 & 0.67 & 0.57 & 54.55 & 0.00 & 9.09 & 9.09 & 9.09 & 18.18 \\
\hline UE2 & Summer & 4820 & 25 & 2.16 & 3.69 & 0.59 & 0.47 & 44.00 & 16.00 & 4.00 & 8.00 & 12.00 & 16.00 \\
\hline UE3 & Summer & 830 & 6 & 2.02 & 1.05 & 0.72 & 0.78 & 33.33 & 0.00 & 16.67 & 16.67 & 0.00 & 33.33 \\
\hline UE4 & Summer & 491 & 3 & 1.45 & 0.47 & 0.61 & 0.91 & 0.00 & 0.00 & 33.33 & 0.00 & 0.00 & 66.67 \\
\hline LE5 & Summer & 216 & 4 & 0.63 & 0.88 & 0.19 & 0.31 & 50.00 & 25.00 & 25.00 & 0.00 & 0.00 & 0.00 \\
\hline LE6 & Summer & 1457 & 7 & 1.03 & 1.13 & 0.32 & 0.37 & 57.14 & 0.00 & 14.29 & 0.00 & 0.00 & 28.57 \\
\hline LE7 & Summer & 2670 & 23 & 2.52 & 3.72 & 0.67 & 0.56 & 47.83 & 4.35 & 8.70 & 0.00 & 4.35 & 34.78 \\
\hline LE8 & Summer & 2583 & 23 & 3.18 & 3.74 & 0.82 & 0.70 & 56.52 & 0.00 & 8.70 & 0.00 & 8.70 & 26.09 \\
\hline LE9 & Summer & 11212 & 32 & 0.48 & 4.22 & 0.09 & 0.10 & 25.00 & 3.13 & 15.63 & 0.00 & 18.75 & 37.50 \\
\hline UE1 & Autumn & 491 & 13 & 2.79 & 2.84 & 0.80 & 0.75 & 30.77 & 23.08 & 7.69 & 0.00 & 23.08 & 15.38 \\
\hline UE2 & Autumn & 2403 & 23 & 3.15 & 3.79 & 0.80 & 0.70 & 34.78 & 13.04 & 4.35 & 0.00 & 34.78 & 13.04 \\
\hline UE3 & Autumn & 1335 & 8 & 1.29 & 1.34 & 0.42 & 0.43 & 62.50 & 0.00 & 0.00 & 0.00 & 25.00 & 12.50 \\
\hline UE4 & Autumn & 505 & 12 & 2.57 & 2.59 & 0.78 & 0.72 & 58.33 & 0.00 & 16.67 & 0.00 & 16.67 & 8.33 \\
\hline LE5 & Autumn & 2020 & 11 & 2.00 & 1.77 & 0.60 & 0.58 & 54.55 & 0.00 & 0.00 & 0.00 & 0.00 & 45.45 \\
\hline LE6 & Autumn & 599 & 21 & 3.94 & 4.53 & 0.93 & 0.90 & 52.38 & 0.00 & 4.76 & 4.76 & 23.81 & 14.29 \\
\hline LE7 & Autumn & 2316 & 31 & 3.19 & 5.20 & 0.75 & 0.64 & 35.48 & 0.00 & 6.45 & 3.23 & 16.13 & 38.71 \\
\hline LE8 & Autumn & 2648 & 36 & 2.84 & 5.93 & 0.66 & 0.55 & 30.56 & 5.56 & 5.56 & 2.78 & 8.33 & 47.22 \\
\hline LE9 & Autumn & 13485 & 69 & 2.84 & 9.03 & 0.68 & 0.47 & 31.88 & 1.45 & 7.25 & 7.25 & 17.39 & 34.78 \\
\hline UE1 & Winter & 9632 & 21 & 0.79 & 2.78 & 0.18 & 0.18 & 33.33 & 19.05 & 0.00 & 4.76 & 23.81 & 19.05 \\
\hline UE2 & Winter & 4906 & 17 & 1.57 & 2.45 & 0.41 & 0.38 & 47.06 & 17.65 & 11.76 & 5.88 & 5.88 & 11.76 \\
\hline UE3 & Winter & 981 & 4 & 1.05 & 0.61 & 0.48 & 0.53 & 50.00 & 0.00 & 0.00 & 0.00 & 25.00 & 25.00 \\
\hline UE4 & Winter & 1522 & 6 & 0.99 & 0.93 & 0.34 & 0.38 & 66.67 & 0.00 & 0.00 & 0.00 & 16.67 & 16.67 \\
\hline LE5 & Winter & 2756 & 19 & 2.64 & 3.03 & 0.78 & 0.62 & 47.37 & 5.26 & 0.00 & 5.26 & 5.26 & 36.84 \\
\hline LE6 & Winter & 4278 & 27 & 3.30 & 4.07 & 0.86 & 0.69 & 51.85 & 3.70 & 7.41 & 3.70 & 14.81 & 18.52 \\
\hline LE7 & Winter & 6934 & 62 & 3.81 & 8.88 & 0.83 & 0.64 & 46.77 & 3.23 & 4.84 & 3.23 & 16.13 & 25.81 \\
\hline LE8 & Winter & 3413 & 48 & 4.04 & 7.63 & 0.87 & 0.72 & 50.00 & 0.00 & 8.33 & 2.08 & 14.58 & 25.00 \\
\hline LE9 & Winter & 20022 & 58 & 1.66 & 7.19 & 0.35 & 0.28 & 37.93 & 1.72 & 6.90 & 5.17 & 18.97 & 29.31 \\
\hline UE1 & Spring & 18319 & 21 & 0.98 & 2.55 & 0.27 & 0.22 & 44.44 & 22.22 & 0.00 & 5.56 & 11.11 & 16.67 \\
\hline UE2 & Spring & 5368 & 24 & 1.74 & 3.48 & 0.46 & 0.38 & 41.67 & 20.83 & 8.33 & 0.00 & 16.67 & 12.50 \\
\hline UE3 & Spring & 1198 & 9 & 2.42 & 1.56 & 0.78 & 0.76 & 55.56 & 0.00 & 0.00 & 0.00 & 22.22 & 22.22 \\
\hline UE4 & Spring & 3802 & 8 & 0.34 & 1.12 & 0.08 & 0.11 & 50.00 & 12.50 & 12.50 & 0.00 & 12.50 & 12.50 \\
\hline LE5 & Spring & 3629 & 7 & 0.91 & 0.96 & 0.33 & 0.32 & 42.86 & 0.00 & 14.29 & 14.29 & 0.00 & 28.57 \\
\hline LE6 & Spring & 1941 & 28 & 3.14 & 4.83 & 0.80 & 0.65 & 46.43 & 0.00 & 10.71 & 0.00 & 21.43 & 21.43 \\
\hline LE7 & Spring & 6486 & 59 & 4.15 & 8.53 & 0.88 & 0.71 & 47.46 & 1.69 & 11.86 & 3.39 & 15.25 & 20.34 \\
\hline LE8 & Spring & 7417 & 63 & 4.62 & 8.94 & 0.93 & 0.77 & 41.27 & 1.59 & 12.70 & 3.17 & 17.46 & 23.81 \\
\hline LE9 & Spring & 1876 & 33 & 3.30 & 5.75 & 0.81 & 0.65 & 48.48 & 0.00 & 6.06 & 3.03 & 21.21 & 21.21 \\
\hline
\end{tabular}

\section{Analysis of benthic macroinvertebrate communities}

Two different communities were determined according to the ordination of stations and taxa of the MDS analysis based on macroinvertebrate abundance. The ordination showed two definite groups of sampling stations: those corresponding to the upper estuary (UE) and lower estuary (LE) respectively (Fig. 2). The UE group (UE1-UE4) included stations located in the upper estuary stretch and corresponded to a freshwater community, whereas the second group comprised the lower estuary stations (LE5-LE9) and had a community with a large marine influence. In addition, we also applied the MDS analysis considering lower taxonomic categories e.g. genus and family; the results obtained showed the same grouping of stations regardless of the taxonomic level employed in the ordinations. Significant differences in community composition were found between these two groups (ANOSIM r: 0.891, $p<0.001)$. Significant differences were also found among stations (ANOSIM global r: 0.694, $p<0.001$ ) except for the following pairs: UE1-UE3, UE3-UE4, UE4-LE5, LE5-LE6, LE6-LE7, LE6-LE8, LE7-LE8, LE7-LE9 and LE8-LE9, $p>0.05$ (Table 3).
The SIMPER analysis showed that the mean community similarity within the UE group was $32.30 \%$. The taxa that most contributed to the high similarity among stations were C. fluminea (27.26\%), Tubificidae (18.34\%), Naididae (12.02\%) and Chironomidae (17.00\%). The mean similarity of the LE group was $29.67 \%$ with a high contribution from S. benedicti (10.44\%), Corophium orientale $(8.56 \%)$ and Caulleriella zetlandica (6.01\%). The similarity contribution of taxa within this group was more balanced than in the UE group, since a total of 35 taxa was necessary to accumulate $90 \%$ of the similarity. The mean dissimilarity between these two groups was $96.58 \%$ with $C$. fluminea, $S$. benedicti, Tubificidae, C. orientale, Naididae, C. zetlandica, Pseudopolydora antennata and Armandia cirrhosa as the taxa with the highest contributions to dissimilarity.

The BIOENV analysis showed that the combination of salinity, dissolved phosphate, total phosphorous, ammonia and the distance from the mouth have a large influence on the structure of the macroinvertebrate communities $(\rho=0.741)$. The combination of salinity, dissolved phosphate, ammonia and nitrate explained the differences in taxa abundance in the upper estuary $(\rho=0.308)$. However, within the community of the lower estuary, the combination of ammonia, total chlorophyll, sand percentage, 


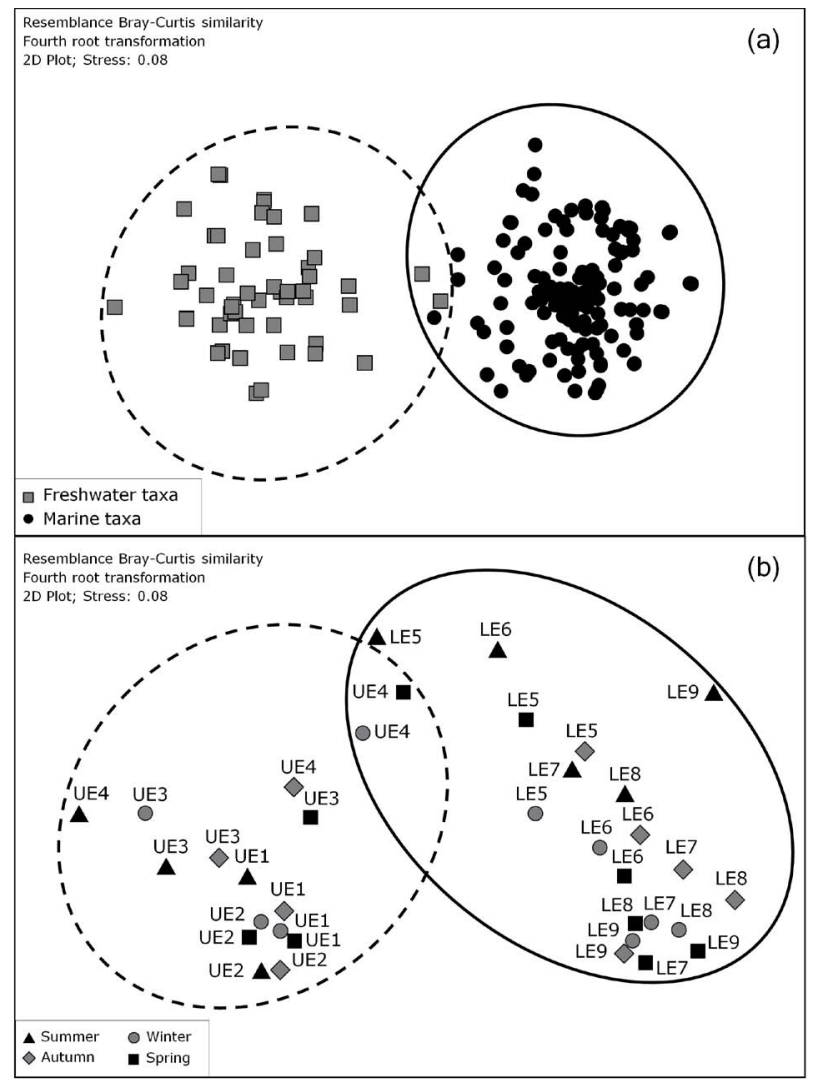

FIG. 2. - Two dimensional MDS plots based on Bray-Curtis similarities of fourth-root transformed macroinvertebrate abundance data: (a) ordination using inter-species resemblance matrix of nine stations; (b) ordination of the nine stations sampled in the Ebro estuary. The dashed line and the solid line encircle the freshwater and marine communities respectively. See Figure 1 for sampling station codes.

TABLE 3. - One-way ANOSIM test to compare the macroinvertebrate communities at different sampling stations. The test results are shown in the lower diagonal of the table. Significant differences between stations $(P<0.05)$ are indicated $(*)$. The $R$ values are shown in bold letters in the upper diagonal of the table. See Figure 1 for sampling station codes.

\begin{tabular}{lccccccccc}
\hline & UE1 & UE2 & UE3 & UE4 & LE5 & LE6 & LE7 & LE8 & LE9 \\
\hline UE1 & & $\mathbf{0 . 7 0 8}$ & $\mathbf{0 . 4 5 8}$ & $\mathbf{0 . 5 5 2}$ & $\mathbf{1 . 0 0 0}$ & $\mathbf{1 . 0 0 0}$ & $\mathbf{1 . 0 0 0}$ & $\mathbf{1 . 0 0 0}$ & $\mathbf{1 . 0 0 0}$ \\
UE2 & $0.029^{*}$ & & $\mathbf{0 . 7 1 9}$ & $\mathbf{0 . 6 3 5}$ & $\mathbf{1 . 0 0 0}$ & $\mathbf{1 . 0 0 0}$ & $\mathbf{1 . 0 0 0}$ & $\mathbf{1 . 0 0 0}$ & $\mathbf{1 . 0 0 0}$ \\
UE3 & 0.057 & $0.029^{*}$ & & $\mathbf{0 . 2 1 9}$ & $\mathbf{0 . 9 1 7}$ & $\mathbf{0 . 9 9 0}$ & $\mathbf{1 . 0 0 0}$ & $\mathbf{1 . 0 0 0}$ & $\mathbf{1 . 0 0 0}$ \\
UE4 & $0.029^{*}$ & $0.029^{*}$ & 0.143 & & $\mathbf{0 . 3 0 2}$ & $\mathbf{0 . 6 8 8}$ & $\mathbf{0 . 8 4 9}$ & $\mathbf{0 . 8 8 5}$ & $\mathbf{0 . 8 8 0}$ \\
LE5 & $0.029^{*}$ & $0.029^{*}$ & $0.029^{*}$ & 0.114 & & $\mathbf{0 . 2 1 9}$ & $\mathbf{0 . 5 4 2}$ & $\mathbf{0 . 6 6 7}$ & $\mathbf{0 . 6 0 4}$ \\
LE6 & $0.029^{*}$ & $0.029^{*}$ & $0.029^{*}$ & $0.029^{*}$ & 0.143 & & $\mathbf{0 . 1 6 7}$ & $\mathbf{0 . 1 1 5}$ & $\mathbf{0 . 4 4 8}$ \\
LE7 & $0.029^{*}$ & $0.029^{*}$ & $0.029^{*}$ & $0.029^{*}$ & $0.029^{*}$ & 0.171 & & $\mathbf{0 . 0 0 0}$ & $\mathbf{0 . 2 4 0}$ \\
LE8 & $0.029^{*}$ & $0.029^{*}$ & $0.029^{*}$ & $0.029^{*}$ & $0.029^{*}$ & 0.200 & 1.000 & & $\mathbf{0 . 0 8 3}$ \\
LE9 & $0.029^{*}$ & $0.029^{*}$ & $0.029^{*}$ & $0.029^{*}$ & $0.029^{*}$ & $0.029^{*}$ & 0.086 & 0.229 & \\
\hline
\end{tabular}

TOM and the permanence time of the salt wedge showed the highest correlation and explained the main differences in the macroinvertebrate abundance data $(\rho=0.681)$

\section{DISCUSSION}

The whole Ebro estuary is dominated by sand; however, the percentage of fine deposits such as clay or mud was higher in the lower stretch due to flocculation and settling processes and low velocities recorded at the salt wedge (Sierra et. al., 2002). During the study period the bottom water layer of the estuary showed important differences in physicochemical features between the lower and upper estuary stretches. We found freshwater stations (UE1-UE4) that were not exposed to marine intrusions, and saltwater stations (LE5-LE9) that were permanently exposed to marine intrusions and had a well stratified water column. At LE stations, salinity in the salt wedge decreased upstream with small fluctuations but with values always higher than 30 , which evidences the weak mixing between water layers. In highly stratified estuaries the salt wedge dynamics are complex and can be explained by a combination of hydromorphological factors, such as the tide amplitude, river channel cross section and flow, and the freshwater runoff is one of the main factors determining the salt wedge regime (Ibáñez et al., 1997). Nevertheless, in the lower estuary the salt wedge was present on all sampling occasions and the permanence time almost reached a complete year. Although other long periods of marine intrusion in the Ebro estuary have been recorded before (Ibáñez et al., 1995), under natural conditions this period should be approximately 6 months per year (Ibáñez et al., 1997). These conditions of the quasi permanent presence of the salt wedge in the lower estuary stretch are exacerbated by the strong flow regulation and the almost total absence of peak flows, which leads to reduced turbulence and therefore to highly stable densitythermal stratification (Ibáñez et al., 1995, 1996).

The present conditions of nutrient loading of the Ebro estuary are quite different from the past situation of eutrophication (Ibáñez et al., 1995). Under eutrophic conditions, and with long periods of permanence of the salt wedge in the lower estuary at the same time, the water quality was worse below the wedge than above it due to organic matter deposition and low water renewal. This organic enrichment caused oxygen depletion through microbial consumption (Ibáñez et al., 1995; Casamayor et al., 2001). Recent changes in the nutrient content of the river, especially the reduction of phosphates, have reduced the primary production in the upper layer, whereas in the lower layer it has increased due to higher light penetration (Falco et al., 2010); thus, the hypoxic conditions in the lower layer have decreased (Casamayor et al., 2001; Ibáñez et al., 2008).

Under the present oligotrophication process, the long periods of salt wedge permanence ensure the stability of the water column, which allows the complexity of the benthic communities to increase, as suggested by Sousa et al. (2006a). The present situation is very different to that of the early nineties, when a survey conducted in October 1992 showed an impoverished macroinvertebrate community (only seven different taxa were found) due to eutrophication, which caused severe anoxic episodes below the halocline (Ibáñez et al., 1995).

The benthic macroinvertebrate community in the Ebro estuary shows considerable spatial and temporal differences, with a complex structure and composition. The multivariate analysis defined two different communities: one from the lower and one from the upper 
estuary stretch. In contrast, the pattern described in more mixed estuaries (Rundle et al., 1998; Ysebaert et al., 1998; Sousa et al., 2008) supports the idea that these systems work as a continuum of overlapping communities along the salinity gradient, which fits with the ecocline boundary model suggested by Attrill and Rundle (2002). However, the weak longitudinal salinity gradient and the narrow transition zone between fresh and marine water suggest that the Ebro estuary fits much better into an ecotone model, when ecotone is defined as an area of relatively rapid change that produces a narrow ecological zone between two different and homogeneous community types (Van der Maarel, 1990).

The upper stretch of the Ebro estuary was characterized by an impoverished macroinvertebrate community dominated by the non-indigenous bivalve $C$. fluminea, which tends to acquire an invasive pattern (Sousa et al., 2006b), together with tolerant taxa such as Tubificidae, Naididae (Oligochaeta) and abundant Chiromidae. The amphipod $C$. orientale was well-represented in number of individuals but its presence was restricted to stations UE3 and UE4 located close to the salt wedge tip due to its euryhaline nature. The salt wedge community was dominated in terms of abundance by the Polychaeta and Malacostraca classes, followed by the phylum Mollusca. Nevertheless, in terms of richness it was dominated by molluscs, polychaetes and crustaceans in this order. This pattern was slightly different from those found in other temperate intertidal areas, where polychaetes are the most diverse group, followed by molluscs and crustaceans (Ysebaert et al., 1998; Rodrigues et al., 2006). Comparing our results with those from other European estuarine ecosystems we found that the Ebro estuary was colonized in its mouth area by typical marine species associated with the Abra alba-Lagis koreni community (colonizing fine sediments rich in organic matter) and with the Nephtys spp. community (colonizing sandy sediments). These two communities are widely distributed throughout European estuarine and coastal areas (Dauvin, 2000, 2007; Martín et al., 2000; Van Hoey et al., 2004; Puente et al., 2008). In addition to these communities, we also found tolerant groups dominated by Capitellidae and Spionidae (Polychaeta), together with Corbula gibba, which usually colonizes disturbed areas; whereas in the upper stations close to the null point the community was dominated by eurybiontic taxa like $\mathrm{He}$ diste diversicolor, Perinereis cultrifera, Heteromastus filiformis, C. orientale and Cyathura carinata. These species are also very common in other European estuaries and coastal areas (Marques et al., 1993; Ysebaert et al., 1998, 2003; Martín et al., 2000; Chainho et al., 2006; Rodrigues et al., 2006; Sousa et al., 2006a, 2008).

Currently, the Ebro estuary shows high levels of richness compared with other European estuaries (Rodrigues et al., 2006). The trophic structure is well represented with six different trophic guilds. Deposit feeders, suspension feeders and predators are dominant, which suggests that different resources are available (Brown et al., 2000). In the upper stretch the diversity and richness decreased seawards, with minimum values found close to the null point because the salinity fluctuation is a physiological barrier for stenohaline freshwater and marine taxa (Mannino and Montagna, 1997). However, diversity and richness at the salt wedge stations declined with increasing distance from the sea, which is a recurring tendency in mixed estuaries (Remane and Schleiper, 1971; Schlacher and Woolbridge, 1996). In the Ebro estuary this impoverishment tendency could be explained by the increase in organic matter, ammonia and total phosphorous towards the tip of the salt wedge in combination with the salinity fluctuations in the same area.

The present study provides baseline data that can be used in future ecological studies on this important Mediterranean estuarine ecosystem, as well as in comparisons with other highly stratified estuaries. Complementary studies are necessary to improve our understanding of the spatial and temporal variability of the macrozoobenthic estuarine community. This knowledge could be an important tool for conserving the biodiversity in the Ebro estuary and could be used to develop biological indices for assessing its ecological status according to the Water Framework Directive of the European Union.

\section{ACKNOWLEDGEMENTS}

This research was supported by the Government of Catalonia (Catalan Water Agency, ACA). We are very grateful to C. Buendía, Ll. Jornet, C. Macaigne, D. Mateu, M. San Lorenzo and R. Valmaña for field assistance and laboratory work. Many thanks to $\mathbf{M}$. González-Porto for helping us with Polychaeta identification and to C. Reverté for the bibliographic search.

\section{REFERENCES}

AENOR. - 1996. Norma UNE-EN 872. Water quality. Determination of total suspended solids. AENOR, Madrid, Spain.

Attrill, M.J. and S.D. Rundle. - 2002. Ecotone or ecocline: Ecological boundaries in estuaries. Est. Coast. and Shelf Sci., 55: 929-936.

Batalla, R.J., C.M. Gómez and G.M. Kondolf. - 2004. Reservoirinduced hydrological changes in the Ebro River basin (NE Spain). J. Hydrol., 290: 117-136.

Brown, S.S., G.R. Gaston, C.F. Rakocinski and R.W. Heard. 2000. Effects of sediment contaminants and environmental gradients on macrobenthic community trophic structure in Gulf of Mexico estuaries. Estuaries, 23: 411-424.

Cacchione, D.A., D.E. Drake, M.A. Losada and R. Medina. - 1990. Bottom-boundary layer measurements on the continental shelf off the Ebro River, Spain. Mar. Geol., 95: 179-192.

Caiola, N., M.J. Vargas and A. Sostoa. - 2001. Feeding ecology of the endangered Valencia toothcarp, Valencia hispanica (Actinopterygii: Valenciidae). Hydrobiologia, 448: 97-105.

Capaccioni-Azzati, R. and D. Martín. - 1992. Pseudomastus deltaicus gen. et sp. n. (Polychaeta: Capitellidae) from a shallow water bay in the North-western Mediterranean Sea. Zool. Scr., 21: $247-250$.

Casamayor, E.O., J. Garcia-Cantizano, J. Mas and C. Pedros-Alio. - 2001. Primary production in estuarine oxic/anoxic interfaces: contribution of microbial dark $\mathrm{CO}_{2}$ fixation in the Ebro River Salt Wedge Estuary. Mar. Ecol. Prog. Ser., 215: 49-56.

Chainho, P., J.L. Costa, M.L. Chaves, M.F. Lane, D.M. Dauer and 
M.J. Costa. - 2006. Seasonal and spatial patterns of distribution of subtidal benthic invertebrate communities in the Mondego River, Portugal - a poikilohaline estuary. Hydrobiologia, 555: 59-74.

Clarke, K.R. and R.N. Gorley. - 2006. PRIMER v6: User Manual/ Tutorial. PRIMER-E, Plymouth, UK.

Clarke, K.R. and R.M. Warwick. - 2001. Change in Marine Communities: An Approach to Statistical Analysis and Interpretation, second ed. PRIMER-E, Plymouth, UK, 00-165.

Dajoz, R. - 1971. Précis d'Ecologie. Dunod, París, France.

Dauer, D.M., J.A. Ranasinghe and S.B. Weisberg. - 2000. Relationships between benthic community condition, water quality, sediment quality, nutrient loads, and land use patterns in Chesapeake Bay. Estuaries, 23: 80-96.

Dauvin, J.C. - 2000. The muddy fine sand Abra alba-Melinna palmata community of the Bay of Morlaix twenty years after the Amoco Cadiz oil spill. Mar. Pollut. Bul., 40: 528-536.

Dauvin, J.C. - 2007. Paradox of estuarine quality: benthic indicators and indices, consensus or debate for the future. Mar. Pollut. Bul., 55: 271-281.

Elliott, M. and V. Quintino. - 2007. The estuarine quality paradox, environmental homeostasis and the difficulty of detecting anthropogenic stress in naturally stressed areas. Mar. Pollut. Bul., 54: 640-645.

Falco, S., L.F. Niencheski, M. Rodilla, I. Romero, J. González del Río, J.P. Sierra and C. Mosso. - 2010. Nutrient flux and budget in the Ebro estuary. Est. Coast. and Shelf Sci., 87: 92-102.

Ferreira, T., N. Caiola, F. Casals, J.M. Oliveira and A. Sostoa. 2007a. Assessing perturbation of river fish communities in the Iberian Ecoregion. Fisheries Manag. Ecol., 14: 519-530.

Ferreira, T., J.M. Oliveira, N. Caiola, A. Sostoa, F. Casals, R. Cortes, A. Economou, S., Zogaris, D. Garcia-Jalón, M. Ilhéu, F. Martínez-Capel, D. Pont, C. Rogers and J. Prenda. - 2007b. Ecological traits of fish assemblages from Mediterranean Europe and their responses to human disturbance. Fisheries Manag. Ecol., 14: 473-481.

Field, J.G., K.R. Clarke and R.M. Warwick. - 1982. A practical strategy for analyzing multispecies distribution patterns. Mar. Ecol. Prog. Ser., 8: 7-52.

Gray, J.S., M. Elliott. - 2009. The ecology of marine sediments. Second edition Cambridge University Press, Cambridge, UK.

Hansen, D.V. and M. Rattray. - 1966. New dimensions in estuary classification. Limnol. Oceanogr., 11: 319-326.

Holme, N.A. and A.D. McIntyre. - 1984. Methods for the study of marine benthos. Blackwell Scientific Publications. London, UK.

Ibáñez, C., A. Rodrigues-Capítulo and N. Prat. - 1995. The combined impacts of river regulation and eutrophication on the dynamics of the salt wedge and the ecology of the lower Ebro River. In The ecological basis for river management, ed. D. Harper and A. Ferguson, 105-114. John Wiley and Sons, Chichester, UK

Ibáñez, C., N. Prat and A. Canicio. - 1996. Changes in the hydrology and sediment transport produced by large dams on the lower Ebro River and its estuary. Regul. Rivers: Res. Manage., 12: $51-62$

Ibáñez, C., D. Pont and N. Prat. - 1997. Characterization of the Ebre and Rhone estuaries: A basis for defining and classifying saltwedge estuaries. Limnol. Oceanogr., 42: 89-101.

Ibáñez, C., J. Saldaña and N. Prat. - 1999. A model to determine the advective circulation in a three layer, salt wedge estuary: application the Ebre River estuary. Est. Coast. Shelf Sci., 48: 271-279.

Ibáñez, C., N. Prat, C. Durán, M. Prados, A. Munné, R. Andreu, N. Caiola, N. Cid, H. Hampel, R. Sánchez and R. Trobajo. - 2008. Changes in dissolved nutrients in the lower Ebro river: Causes and consequences. Limnética, 27: 131-142.

Jeffrey, S.W. and G.F. Humphrey. - 1975. New spectrophotometric equations for determining chlorophylls $\mathrm{a}, \mathrm{b}, \mathrm{c}_{1}$ and $\mathrm{c}_{2}$ in higher plants, algae and natural phytoplankton. Biochem. Physiol. Pflanzen, 167: 191-194.

Koroleff, F. - 1977. Simultaneous persulphate oxidation of phosphorus and nitrogen compounds in water. In report of the Baltic Intercalibration Worshop, 52-53.

Kristensen, E. and F.O. Andersen. - 1987. Determination of organic-carbon in marine-sediments - a comparison of $2 \mathrm{chn}$-analyzer methods. J. Exp. Mar. Biol. Ecol., 109: 15-23.

Legendre, P and L. Legendre. - 1998. Numerical ecology. Elsevier, Amsterdam, Netherlands.

Mannino, A. and P.A. Montagna. - 1997. Small-scale spatial variation of macrobenthic community structure. Estuaries, 20: 159-173.

Marques, J.C., P. Maranhao and M.A. Pardal. - 1993. Human impact assessment on the subtidal macrobenthic community structure in the Mondego estuary (western Portugal). Est. Coast. and Shelf Sci., 37: 403-419.

Martín, D., S. Pinedo and R. Sardá. - 2000. Distribution patterns and trophic structure of soft-bottom Polychaete assemblages in a northwestern Mediterranean shallow-water Bay. Ophelia, 53: 1-17.

McLusky, D.S. - 1999. Estuarine benthic ecology: A European perspective. Aust. J. Ecol., 24: 302-311.

Morrisey, D.J., L. Howitt, A.J. Underwood and J.S. Stark. - 1992 Spatial variation in soft-sediment benthos. Mar. Ecol. Prog. Ser., 81: 197-204.

Puente, A., J.A. Juanes, A. García, C. Álvarez, J.A. Revilla and I. Carranza. - 2008. Ecological assessment of soft bottom benthic communities in northern Spanish estuaries. Ecol. Indic., 8: 373-388.

Remane, A. and C. Schlieper. - 1971. Biology of brackish water. Wiley Interscience, New York, USA.

Rodrigues, A.M., S. Meireles, T. Pereira, A. Gama and V. Quintino. - 2006. Spatial patterns of benthic macroinvertebrates in intertidal areas of a Southern european estuary: the Tagus, Portugal. Hydrobiologia, 555: 99-113.

Rovira, L., R. Trobajo and C. Ibáñez. - 2009. Periphytic diatom community in a Mediterranean salt wedge estuary: the Ebro Estuary (NE Iberian Peninsula). Acta Bot. Croat., 68: 285-300.

Rundle, S.D., M.J. Attrill and A. Arshad. - 1998. Seasonality in macroinvertebrate community composition across a neglected ecological boundary, the freshwater-estuarine transition zone. Aquat.Ecol., 32: 211-216.

Schlacher, T.A. and T.H. Wooldridge. - 1996. Axial zonation patterns of subtidal macrozoobenthos in the Gamtoos estuary, South Africa. Estuaries, 19: 680-696.

Sierra, J.P., A. Sánchez-Arcilla, J.G. Del Río, J. Flos, E. Movellán, C. Mosso, R. Martínez, M. Rodilla, S. Falco and I. Romero. 2002. Spatial distribution of nutrients in the Ebro estuary and plume. Cont. Shelf Res., 22: 361-378.

Sierra, J.P., A. Sánchez-Arcilla, P.A. Figueras, J.G. Del Río, E.K Rassmussen and C. Mosso. - 2004. Effects of discharge reductions on salt wedge dynamics of the Ebro River. River Res. Appl., 20: 61-77.

Sousa, R., S. Dias and J.C. Antunes. - 2006a. Spatial subtidal macrobenthic distribution in relation to abiotic conditions in the Lima estuary, NW of Portugal. Hydrobiologia, 559: 135-148.

Sousa, R., C. Antunes and L. Guilhermino. - 2006b. Factors influencing the occurrence and distribution of Corbicula fluminea (Müller, 1774) in the River Lima estuary. Ann. Limnol., 42: 165-171.

Sousa, R., S. Dias, V. Freitas and C. Antunes. - 2008. Subtidal macrozoobenthic assemblages along the River Minho estuarine gradient (north-west Iberian Peninsula). Aquatic Conserv: Mar. Freshw. Ecosyst., 18: 1063-1077.

Van der Maarel, E. - 1990. Ecotones and ecoclines are different. $J$. Veg. Sci., 1: 135-138.

Van Hoey, G., S. Degraer, M. Vincx. - 2004. Macrobenthic community structure of soft-bottom sediments at the Belgian Continental Shelf. Est. Coast. and Shelf Sci., 59: 599-613.

Ysebaert, T., P. Meire, J. Coosen and K. Essink. - 1998. Zonation of intertidal macrobenthos in the estuaries of Schelde and Ems. Aquat.Ecol., 32: 53-71.

Ysebaert, T., P.M.J. Herman, P. Meire, J. Craeymeersch, H. Verbeek and C.H.R. Heip. - 2003. Large-scale spatial patterns in estuaries: estuarine macrobenthic communities in the Schelde estuary, NW Europe. Est. Coast. and Shelf Sci., 57: 335-355.

Scient. ed.: J.S. Troncoso.

Received October 15, 2010. Accepted February 7, 2011.

Published online June 6, 2011.

\section{SUPPLEMENTARY MATERIAL}

The following Appendix is available through the web page http://www.icm.csic.es/scimar/supplm/sm75n3577sm.pdf

ApPENDIX 1. - List of the identified taxa that were found at all the stations over the entire study period. 
Community structure of benthic macroinvertebrates inhabiting a highly stratified Mediterranean estuary

ALFONSO NEBRA, NUNO CAIOLA and CARLES IBÁÑEZ

Supplementary material 
ApPendix 1. - List of the identified taxa that were found at all the stations over the entire study period. The stations where each taxon was found are also listed. See Figure 1 for sampling station codes; FG, feeding guild (see Table 2 for feeding guild codes); CI, Constancy index; $\mathrm{Ct}$, constant; $\mathrm{VC}$, very common; $\mathrm{C}$, common; $\mathrm{UC}$, uncommon; $\mathrm{R}$, rare.

\begin{tabular}{|c|c|c|c|c|c|c|c|c|}
\hline Taxa & Summer & Autumn & Winter & Spring & FG & CI & $\begin{array}{l}\text { CI } \\
\text { UE }\end{array}$ & $\begin{array}{l}\text { CI } \\
\text { LE }\end{array}$ \\
\hline \multicolumn{9}{|l|}{ PHYLUM CNIDARIA } \\
\hline \multicolumn{9}{|l|}{ Class Anthozoa } \\
\hline \multirow{3}{*}{\multicolumn{9}{|c|}{$\begin{array}{l}\text { Dladumene sp. } \\
\text { PHYLUM PLATYHELMINTHES }\end{array}$}} \\
\hline & & & & & & & & \\
\hline \multicolumn{5}{|l|}{ Class Turbellaria } & & & & \\
\hline Dugesia sp. & UE2 & UE2 & & UE2 & $\operatorname{Pr}$ & $\mathrm{R}$ & UC & \\
\hline Turbellaria indet. & & UE2 & UE1 & & $\operatorname{Pr}$ & $\mathrm{UC}$ & $\mathrm{C}$ & \\
\hline \multicolumn{9}{|l|}{ PHYLUM NEMERTINA } \\
\hline \multicolumn{9}{|l|}{ Class Enopla } \\
\hline Nemertina indet. & & LE6,7,9 & LE5,6,7,8,9 & LE6,7,8,9 & $\operatorname{Pr}$ & $\mathrm{VC}$ & & $\mathrm{Ct}$ \\
\hline Prostoma graecense (Böhmig, 1892) & & UE2 & UE1,2,4 & UE2 & Pr & $\mathrm{C}$ & $\mathrm{VC}$ & \\
\hline \multicolumn{9}{|l|}{ PHYLUM NEMATODA } \\
\hline \multirow{2}{*}{\multicolumn{9}{|c|}{ PHYLUM MOLLUSCA }} \\
\hline & & & & & & & & \\
\hline \multicolumn{9}{|l|}{ Class Gastropoda } \\
\hline Aplysiidae indet. & LE9 & LE8 & & & G & $\mathrm{UC}$ & & $\mathrm{C}$ \\
\hline Bittium reticulatum (da Costa, 1778) & & LE8,9 & LE7,8,9 & LE7,8,9 & $\mathrm{DF}$ & $\mathrm{C}$ & & $\mathrm{VC}$ \\
\hline Buсcinum sp. & LE9 & & & & $\mathrm{O}$ & $\mathrm{R}$ & & UC \\
\hline Chrysallida sp. & & LE6,7,8,9 & LE5,6,7,8,9 & LE5,7,8,9 & $\mathrm{Pa}$ & $\mathrm{VC}$ & & $\mathrm{Ct}$ \\
\hline Eulimella polita (Verrill, 1872) & & LE9 & & & $\mathrm{Pa}$ & $\mathrm{R}$ & & UC \\
\hline Ferrissia clessiniana (Jickeli, 1882) & UE2 & UE2 & & UE2 & $\mathrm{G}$ & $\mathrm{R}$ & $\mathrm{UC}$ & \\
\hline Gyraulus albus (Müller, 1774) & & & & $\mathrm{UE} 1,2,4$ & $\mathrm{G}$ & $\mathrm{C}$ & $\mathrm{VC}$ & \\
\hline Haminoea navicula (da Costa, 1778) & & & LE6,7 & & $\mathrm{G}$ & $\mathrm{UC}$ & & $\mathrm{C}$ \\
\hline Hinia limata (Chemnitz, 1795) & LE9 & LE9 & & LE9 & $\operatorname{Pr}$ & $\mathrm{R}$ & & UC \\
\hline Hydrobia sp. & LE7 & & LE5 & LE7 & $\mathrm{G}$ & $\mathrm{UC}$ & & $\mathrm{C}$ \\
\hline Hydrobia ulvae (Pennant, 1777) & & & LE7 & & $\mathrm{G}$ & $\mathrm{R}$ & & UC \\
\hline Mangelia sp. & & LE9 & & & $\mathrm{O}$ & $\mathrm{R}$ & & UC \\
\hline Melanella polita (Linnaeus, 1758) & & & LE9 & & $\mathrm{Pa}$ & $\mathrm{R}$ & & UC \\
\hline Nassarius mutabilis (Linnaeus, 1758) & & LE9 & LE9 & & $\mathrm{O}$ & $\mathrm{R}$ & & UC \\
\hline Nassarius pygmaeus (Lamarck, 1822) & LE7,8,9 & LE9 & & & $\mathrm{O}$ & $\mathrm{C}$ & & $\mathrm{VC}$ \\
\hline Nassarius sp. & & LE7,9 & & & $\mathrm{O}$ & $\mathrm{UC}$ & & $\mathrm{C}$ \\
\hline Neverita josephinia Risso, 1826 & LE9 & LE9 & & & $\operatorname{Pr}$ & $\mathrm{R}$ & & $\mathrm{UC}$ \\
\hline Odostomia conoidea (Brocchi, 1814) & & & & LE8 & $\mathrm{Pa}$ & $\mathrm{R}$ & & UC \\
\hline Odostomia sp. & & LE9 & & & $\mathrm{Pa}$ & $\mathrm{R}$ & & UC \\
\hline Physella acuta (Draparnaud, 1805) & UE2 & UE1,2 & UE1,2 & UE1,2 & $\mathrm{G}$ & $\mathrm{UC}$ & $\mathrm{C}$ & \\
\hline Radix auricularia (Linnaeus, 1758) & & & UE2 & & $\mathrm{G}$ & $\mathrm{R}$ & UC & \\
\hline Radix peregra (Müller, 1774) & UE2 & & UE1 & UE2 & $\mathrm{G}$ & $\mathrm{UC}$ & $\mathrm{C}$ & \\
\hline Retusa truncatula (Bruguière, 1792) & LE8 & LE9 & LE7 & LE6,7,8 & $\mathrm{Pr}$ & $\mathrm{C}$ & & $\mathrm{Ct}$ \\
\hline Rissoa sp. & & LE9 & LE9 & & $\mathrm{G}$ & $\mathrm{R}$ & & UC \\
\hline Rissoa ventricosa Desmarest, 1814 & & & & LE8 & $\mathrm{G}$ & $\mathrm{R}$ & & UC \\
\hline Tricolia sp. & & LE8 & & & $\mathrm{G}$ & $\mathrm{R}$ & & UC \\
\hline Turbonilla lactea (Linnaeus, 1758) & & LE9 & LE7 & LE7 & $\mathrm{Pa}$ & $\mathrm{UC}$ & & $\mathrm{C}$ \\
\hline Turritella sp. & & LE9 & & & $\mathrm{SF}$ & $\mathrm{R}$ & & UC \\
\hline Class Bivalvia & & & & & & & & \\
\hline Abra alba (Wood, 1802) & LE9 & LE5,7,8,9 & LE7,8,9 & LE7,8,9 & SF & $\mathrm{C}$ & & $\mathrm{Ct}$ \\
\hline Abra nitida (Müller, 1776) & & LE9 & LE9 & LE8 & SF & $\mathrm{UC}$ & & $\mathrm{C}$ \\
\hline Acanthocardia echinata (Linnaeus, 1758) & & LE7,8,9 & & & $\mathrm{SF}$ & $\mathrm{C}$ & & $\mathrm{VC}$ \\
\hline Acanthocardia paucicostata (Sowerby, 1841) & LE8 & LE6,7 & LE7,8,9 & LE7,8 & $\mathrm{SF}$ & $\mathrm{C}$ & & $\mathrm{Ct}$ \\
\hline Acanthocardia tuberculata (Linnaeus, 1758) & & & & LE9 & $\mathrm{SF}$ & $\mathrm{R}$ & & UC \\
\hline Cerastoderma edule (Linnaeus, 1758) & & & & LE8 & SF & $\mathrm{R}$ & & UC \\
\hline Cerastoderma glaucum (Poiret, 1789) & & LE8 & LE5,7 & & SF & $\mathrm{C}$ & & $\mathrm{VC}$ \\
\hline Circomphalus casina (Linnaeus, 1758) & LE7 & LE8 & LE8 & & $\mathrm{SF}$ & $\mathrm{UC}$ & & $\mathrm{C}$ \\
\hline Corbicula fluminea (Müller, 1774) & $\mathrm{UE} 1,2,3,4$ & $\mathrm{UE} 1,2,3,4$ & $\mathrm{UE} 1,2,3,4$ & UE1,2,3 & $\mathrm{SF}$ & $\mathrm{C}$ & $\mathrm{Ct}$ & \\
\hline Corbula gibba (Olivi, 1792) & LE7,9 & LE5,6,7,8,9 & LE5,6,7,8,9 & LE5,6,7,8 & $\mathrm{SF}$ & VC & & $\mathrm{Ct}$ \\
\hline Donax semistriatus Poli, 1795 & LE9 & LE9 & & & $\mathrm{SF}$ & $\mathrm{R}$ & & UC \\
\hline Donax sp. & & LE9 & & & SF & $\mathrm{R}$ & & UC \\
\hline Donax trunculus Linnaeus, 1758 & LE7 & & & & $\mathrm{SF}$ & $\mathrm{R}$ & & UC \\
\hline Donax venustus Poli, 1795 & & LE8 & & & $\mathrm{SF}$ & $\mathrm{R}$ & & UC \\
\hline Dosinia lupinus (Linnaeus, 1758) & & LE8,9 & LE7,8,9 & LE8,9 & $\mathrm{SF}$ & $\mathrm{C}$ & & $\mathrm{VC}$ \\
\hline Gari fervensis (Gmelin, 1791) & & LE9 & & & SF & $\mathrm{R}$ & & UC \\
\hline Gastrana fragilis (Linnaeus, 1758) & & & LE9 & & SF & $\mathrm{R}$ & & UC \\
\hline Glycymeris glycymeris (Linnaeus, 1758) & & LE9 & & & SF & $\mathrm{R}$ & & UC \\
\hline Laevicardium crassum (Gmelin, 1791) & & LE8 & & & $\mathrm{SF}$ & $\mathrm{R}$ & & UC \\
\hline Lutraria lutraria (Linnaeus, 1758) & LE9 & & & & $\mathrm{SF}$ & $\mathrm{R}$ & & UC \\
\hline Mactra corallina (Linnaeus, 1758) & LE7,9 & LE7.8 & & & $\mathrm{SF}$ & $\mathrm{C}$ & & VC \\
\hline Mactra sp. & & LE9 & LE9 & & SF & $\mathrm{R}$ & & UC \\
\hline Musculus discors (Linnaeus, 1767) & LE7,8 & LE7,9 & LE5,7 & LE6,7,8 & SF & $\mathrm{VC}$ & & $\mathrm{Ct}$ \\
\hline Mytilus galloprovincialis Lamarck, 1819 & & & & LE8 & $\mathrm{SF}$ & $\mathrm{R}$ & & UC \\
\hline Pandora inaequivalvis (Linnaeus, 1758) & LE7,8 & LE7,8,9 & LE8,9 & LE7 & $\mathrm{SF}$ & $\mathrm{C}$ & & $\mathrm{VC}$ \\
\hline Pharus legumen (Linnaeus, 1758) & & LE9 & & LE9 & $\mathrm{SF}$ & $\mathrm{R}$ & & UC \\
\hline
\end{tabular}


APPENDix 1 (cont.). - List of the identified taxa that were found at all the stations over the entire study period. The stations where each taxon was found are also listed. See Figure 1 for sampling station codes; FG, feeding guild (see Table 2 for feeding guild codes); CI, Constancy index; $\mathrm{Ct}$, constant; $\mathrm{VC}$, very common; C, common; UC, uncommon; R, rare.

\begin{tabular}{|c|c|c|c|c|c|c|c|c|}
\hline Taxa & Summer & Autumn & Winter & Spring & FG & CI & $\begin{array}{l}\text { CI } \\
\text { UE }\end{array}$ & $\begin{array}{l}\text { CI } \\
\text { LE }\end{array}$ \\
\hline Pitar rudis (Poli, 1795) & & LE8 & LE8 & & $\mathrm{SF}$ & $\mathrm{R}$ & & $\mathrm{UC}$ \\
\hline Scrobicularia plana (da Costa, 1778) & LE9 & & & LE8 & $\mathrm{SF}$ & $\mathrm{UC}$ & & $\mathrm{C}$ \\
\hline Solemya togata (Poli, 1795) & & & LE9 & & $\mathrm{SF}$ & $\mathrm{R}$ & & $\mathrm{UC}$ \\
\hline Solen sp. & & LE9 & LE5 & & $\mathrm{SF}$ & $\mathrm{UC}$ & & $\mathrm{C}$ \\
\hline Spisula subtruncata (da Costa, 1778) & LE8,9 & LE9 & LE7 & LE7,8,9 & $\mathrm{SF}$ & $\mathrm{C}$ & & $\mathrm{VC}$ \\
\hline Tapes philippinarum (Adams and Reeve, 1850) & & & LE7 & LE7 & $\mathrm{SF}$ & $\mathrm{R}$ & & $\mathrm{UC}$ \\
\hline Tapes pullastra (Unspecified) & LE7 & LE7,8 & & & $\mathrm{SF}$ & $\mathrm{UC}$ & & $\mathrm{C}$ \\
\hline Tapes sp. & & LE8,9 & LE6,7,8,9 & LE7,8,9 & $\mathrm{SF}$ & $\mathrm{C}$ & & $\mathrm{Ct}$ \\
\hline Tellina albicans (Gmelin, 1791) & & LE8,9 & LE7,9 & LE7 & $\mathrm{SF}$ & $\mathrm{C}$ & & VC \\
\hline Tellina sp. & & LE8,9 & LE7,9 & LE6,9 & $\mathrm{SF}$ & $\mathrm{C}$ & & $\mathrm{Ct}$ \\
\hline Tellina tenuis da Costa, 1778 & & LE9 & LE5,8,9 & LE7 & SF & $\mathrm{C}$ & & $\mathrm{Ct}$ \\
\hline \multicolumn{9}{|l|}{ Class Scaphopoda } \\
\hline Antalis novemcostata (Lamarck, 1818) & & & & LE8 & $\operatorname{Pr}$ & $\mathrm{R}$ & & $\mathrm{UC}$ \\
\hline Antalis sp. & & LE8,9 & LE9 & LE7,8 & $\operatorname{Pr}$ & $\mathrm{C}$ & & $\mathrm{VC}$ \\
\hline \multicolumn{9}{|l|}{ PHYLUM ANNELIDA } \\
\hline \multicolumn{9}{|l|}{ Class Hirudinea } \\
\hline Helobdella stagnalis (Linnaeus, 1758) & UE2 & & & & $\operatorname{Pr}$ & $\mathrm{R}$ & $\mathrm{UC}$ & \\
\hline Piscicola geometra (Linnaeus, 1758) & UE2 & & & & $\mathrm{Pa}$ & $\mathrm{R}$ & $\mathrm{UC}$ & \\
\hline \multicolumn{9}{|l|}{ Class Oligochaeta } \\
\hline Haplotaxidae indet. & & & UE3 & & $\mathrm{DF}$ & $\mathrm{R}$ & $\mathrm{UC}$ & \\
\hline Lumbricidae indet. & UE2 & & & UE1 & $\mathrm{DF}$ & UC & $\mathrm{C}$ & \\
\hline Naididae indet. & UE1,2 & UE1,2,3 & UE1,2,4; LE5 & UE1,2,3,4 & DF & $\mathrm{VC}$ & $\mathrm{Ct}$ & $\mathrm{UC}$ \\
\hline Tubificidae indet. & UE1,2,3; LE5 & $\mathrm{UE} 1,2,3,4$ & UE1,2,3 & UE1,2,3 & $\mathrm{DF}$ & $\mathrm{VC}$ & $\mathrm{Ct}$ & $\mathrm{UC}$ \\
\hline \multicolumn{9}{|l|}{ Class Polychaeta } \\
\hline Ampharete grubei Malmgren, 1865 & LE6,7,8 & LE6,7,8,9 & LE6,7,8,9 & LE6,7,8 & $\mathrm{DF}$ & $\mathrm{C}$ & & $\mathrm{Ct}$ \\
\hline Aricidea sp. & LE8,9 & LE6,7,8,9 & LE7 $, 8,9$ & LE6, $7,8,9$ & $\mathrm{DF}$ & $\mathrm{VC}$ & & $\mathrm{Ct}$ \\
\hline Armandia cirrhosa Filippi, 1861 & LE6,7,8 & LE $5,6,7,9$ & LE5,6,7,9 & LE7,8 & $\mathrm{DF}$ & $\mathrm{VC}$ & & $\mathrm{Ct}$ \\
\hline Capitella capitata (Fabricius, 1780) & LE6 & & LE $5,6,7,8,9$ & LE6,8,9 & $\mathrm{DF}$ & $\mathrm{VC}$ & & $\mathrm{Ct}$ \\
\hline Capitellidae indet. & LE8 & LE7 & & & $\mathrm{DF}$ & $\mathrm{UC}$ & & $\mathrm{C}$ \\
\hline Caulleriella zetlandica (McIntosh, 1911) & LE8 & LE6,7,8,9 & LE6,7,8,9 & LE6,7,8,9 & $\mathrm{DF}$ & $\mathrm{C}$ & & $\mathrm{Ct}$ \\
\hline Cirratulus cirratus (Müller, 1776) & & & LE7,8,9 & LE7,9 & $\mathrm{DF}$ & $\mathrm{C}$ & & VC \\
\hline Clymenura clypeata (Saint-Joseph, 1894) & & & LE7 & LE7,8 & DF & $\mathrm{UC}$ & & $\mathrm{C}$ \\
\hline Diopatra neapolitana Delle Chiaje, 1841 & & & LE8,9 & LE7,9 & $\mathrm{DF}$ & $\mathrm{C}$ & & $\mathrm{VC}$ \\
\hline Eteone picta Quatrefagues, 1865 & & LE6,7,9 & LE7,9 & LE7 & $\operatorname{Pr}$ & $\mathrm{C}$ & & $\mathrm{VC}$ \\
\hline Euclymene oerstedi (Claparède, 1863 ) & & & LE7,8,9 & LE6,7,8 & $\mathrm{DF}$ & $\mathrm{C}$ & & $\mathrm{Ct}$ \\
\hline Eunice harassii Audouin \& Edwards, 1834 & & LE8,9 & LE7 & & $\mathrm{DF}$ & $\mathrm{C}$ & & VC \\
\hline Ficopomatus enigmaticus (Fauvel, 1923) & LE6 & & & & $\mathrm{SF}$ & $\mathrm{R}$ & & $\mathrm{UC}$ \\
\hline Glycera sp. & & LE6,9 & LE6,7,8,9 & LE6,7,8,9 & $\operatorname{Pr}$ & $\mathrm{C}$ & & $\mathrm{Ct}$ \\
\hline Glycera tesselata Grube, 1840 & & & & LE9 & $\operatorname{Pr}$ & $\mathrm{R}$ & & $\mathrm{UC}$ \\
\hline Glycera tridactyla Schmarda, 1861 & LE8,9 & LE6,7 & & & $\operatorname{Pr}$ & $\mathrm{C}$ & & $\mathrm{Ct}$ \\
\hline Harmothoe sp. & & LE6,9 & LE7,8,9 & & $\operatorname{Pr}$ & $\mathrm{C}$ & & $\mathrm{Ct}$ \\
\hline Hediste diversicolor (Müller, 1776) & LE7,8 & LE6,7,8 & LE7,8 & LE5,6,7,8 & $\mathrm{O}$ & $\mathrm{C}$ & & $\mathrm{Ct}$ \\
\hline Heteromastus filiformis (Claparède, 1864) & & LE5,6 & LE7,8,9 & LE6,7,8,9 & DF & $\mathrm{VC}$ & & $\mathrm{Ct}$ \\
\hline Hydroides norvegicus Gunnerus, 1768 & & LE7 & & & $\mathrm{SF}$ & $\mathrm{R}$ & & $\mathrm{UC}$ \\
\hline Lagis koreni Malmgren, 1866 & LE9 & & LE6,9 & & $\mathrm{DF}$ & $\mathrm{UC}$ & & $\mathrm{C}$ \\
\hline Laonice cirrata (Sars, 1851) & & & LE8,9 & & $\mathrm{DF}$ & $\mathrm{UC}$ & & $\mathrm{C}$ \\
\hline Lepidonotus squamatus (Linnaeus, 1758) & & & LE7, 9 & LE8 & $\operatorname{Pr}$ & $\mathrm{C}$ & & VC \\
\hline Lumbrineris sp. & & LE7,8,9 & LE6,7,8 & LE7,8 & $\operatorname{Pr}$ & $\mathrm{C}$ & & $\mathrm{Ct}$ \\
\hline Magelona papillicornis Müller, 1858 & & LE9 & & LE7,9 & $\mathrm{DF}$ & $\mathrm{UC}$ & & $\mathrm{C}$ \\
\hline Melinna palmata Grube, 1870 & & LE6,7,8,9 & LE5,7,8,9 & LE6,7,8 & $\mathrm{DF}$ & $\mathrm{VC}$ & & $\mathrm{Ct}$ \\
\hline Micronephthys maryae San Martín, 1982 & LE7 & LE7,8,9 & LE7,8,9 & LE6,7,8,9 & $\operatorname{Pr}$ & $\mathrm{C}$ & & $\mathrm{Ct}$ \\
\hline Neosabellides oceanica (Fauvel, 1909) & & & LE6,7,8 & LE7 & $\mathrm{DF}$ & $\mathrm{C}$ & & VC \\
\hline Nephtys assimilis Örsted, 1843 & & & & LE9 & $\operatorname{Pr}$ & $\mathrm{R}$ & & $\mathrm{UC}$ \\
\hline Nephtys cirrosa (Ehlers, 1868) & LE9 & & & & $\operatorname{Pr}$ & $\mathrm{R}$ & & $\mathrm{UC}$ \\
\hline Nephtys hombergii Lamarck, 1818 & & & LE9 & & $\operatorname{Pr}$ & $\mathrm{R}$ & & $\mathrm{UC}$ \\
\hline Nephtys sp. & & & & LE6,8 & $\operatorname{Pr}$ & $\mathrm{UC}$ & & $\mathrm{C}$ \\
\hline Nereididae indet. & & & UE4; LE6,7 & UE4 & $\mathrm{DF}$ & $\mathrm{C}$ & $\mathrm{UC}$ & $\mathrm{C}$ \\
\hline Notomastus sp. & & LE9 & LE7,8,9 & & $\mathrm{DF}$ & $\mathrm{C}$ & & $\mathrm{VC}$ \\
\hline Oriopsis armandi (Claparède, 1864) & LE7,8,9 & LE5,7,9 & LE5,6,9 & UE4; LE5,8 & SF & $\mathrm{VC}$ & $\mathrm{UC}$ & $\mathrm{Ct}$ \\
\hline Paradoneis lyra (Southern, 1914) & & LE7,9 & LE6,7,8,9 & LE7,8,9 & $\mathrm{DF}$ & $\mathrm{C}$ & & $\mathrm{Ct}$ \\
\hline Perinereis cultrifera (Grube, 1840) & LE5,6 & UE4 & LE6 & UE4; LE8 & $\mathrm{O}$ & $\mathrm{VC}$ & $\mathrm{UC}$ & $\mathrm{VC}$ \\
\hline Phyllodoce mисоsa Orsted, 1843 & LE9 & LE9 & LE9 & & $\operatorname{Pr}$ & $\mathrm{R}$ & & $\mathrm{UC}$ \\
\hline Phylo foetida (Claparède, 1869$)$ & & & LE8 & LE7 & $\mathrm{DF}$ & $\mathrm{UC}$ & & $\mathrm{C}$ \\
\hline Pista cristata (Müller, 1776) & LE7,8 & LE6,7,8,9 & LE7,8,9 & LE7,8 & $\mathrm{DF}$ & $\mathrm{C}$ & & $\mathrm{Ct}$ \\
\hline Prionospio malmgreni Claparède, 1869 & & LE7,8,9 & LE7,8,9 & LE7,8,9 & $\mathrm{DF}$ & $\mathrm{C}$ & & $\mathrm{VC}$ \\
\hline Pseudopolydora antennata (Claparède, 1869 ) & LE7,8 & LE5,6,9 & LE5,6,7,8,9 & LE6,7,8,9 & $\mathrm{DF}$ & $\mathrm{VC}$ & & $\mathrm{Ct}$ \\
\hline Sabella pavonina Savigny, 1822 & & & LE8 & LE7,8 & $\mathrm{SF}$ & $\mathrm{UC}$ & & $\mathrm{C}$ \\
\hline Sabellidae indet. & LE6 & & LE8, 9 & LE6 & $\mathrm{SF}$ & $\mathrm{C}$ & & $\mathrm{VC}$ \\
\hline Serpula vermicularis Linnaeus, 1767 & & LE5,6,7,8 & LE7 & & SF & $\mathrm{C}$ & & $\mathrm{Ct}$ \\
\hline Sigambra parva (Day, 1963) & & LE9 & LE7,8,9 & LE7,8 & $\operatorname{Pr}$ & $\mathrm{C}$ & & $\mathrm{VC}$ \\
\hline
\end{tabular}


Appendix 1 (cont.). - List of the identified taxa that were found at all the stations over the entire study period. The stations where each taxon was found are also listed. See Figure 1 for sampling station codes; FG, feeding guild (see Table 2 for feeding guild codes); CI, Constancy index; $\mathrm{Ct}$, constant; $\mathrm{VC}$, very common; C, common; UC, uncommon; R, rare.

\begin{tabular}{|c|c|c|c|c|c|c|c|c|}
\hline Taxa & Summer & Autumn & Winter & Spring & FG & $\mathrm{CI}$ & $\begin{array}{l}\text { CI } \\
\text { UE }\end{array}$ & $\begin{array}{l}\text { CI } \\
\text { LE }\end{array}$ \\
\hline Spio filicornis (Müller, 1776) & LE8 & LE5,6,7,9 & LE5 $6,6,7,8,9$ & LE6,7,8,9 & DF & $\mathrm{VC}$ & & $\mathrm{Ct}$ \\
\hline Streblospio benedicti Webster, 1879 & LE7,8,9 & LE $5,6,7,8,9$ & LE5,6,7,8,9 & LE5, $6,8,9$ & $\mathrm{DF}$ & VC & & $\mathrm{Ct}$ \\
\hline Syllidia armata Quatrefages, 1866 & & & LE6,7,8,9 & LE6,7,8,9 & $\operatorname{Pr}$ & $\mathrm{C}$ & & $\mathrm{Ct}$ \\
\hline \multicolumn{9}{|l|}{ PHYLUM ARTHROPODA } \\
\hline Class Arachnida & & & & & & & & \\
\hline Acaridida indet. & & & UE1 & & $\operatorname{Pr}$ & $\mathrm{R}$ & $\mathrm{UC}$ & \\
\hline Halacaridae indet. & & & & UE3 & $\operatorname{Pr}$ & $\mathrm{R}$ & UC & \\
\hline Hydrozetes sp. & & UE2 & & & $\operatorname{Pr}$ & $\mathrm{R}$ & $\mathrm{UC}$ & \\
\hline Lebertia sp. & UE2 & UE2,4 & & & $\operatorname{Pr}$ & $\mathrm{UC}$ & $\mathrm{C}$ & \\
\hline Sperchon sp. & & UE2 & & UE2 & $\operatorname{Pr}$ & $\mathrm{R}$ & $\mathrm{UC}$ & \\
\hline Torrenticola sp. & & $\mathrm{UE} 2,3$ & UE3 & & $\operatorname{Pr}$ & $\mathrm{UC}$ & $\mathrm{C}$ & \\
\hline Class Pantopoda & & & & & & & & \\
\hline Nymphon gracile Leach, 1814 & & & & LE7 & $\mathrm{O}$ & $\mathrm{R}$ & & UC \\
\hline \multicolumn{9}{|l|}{ Class Branchiopoda } \\
\hline Daphnia longispina (Müller, 1776) & LE5 & & & & G & $\mathrm{R}$ & & UC \\
\hline Eurycercus lamellatus (Müller, 1776) & & & & UE1 & G & $\mathrm{R}$ & $\mathrm{UC}$ & \\
\hline Ilyocryptus sordidus (Liévin, 1848) & & & UE1 & & $\mathrm{G}$ & $\mathrm{R}$ & $\mathrm{UC}$ & \\
\hline Simocephalus exspinosus (Koch, 1841) & & UE1 & & & $\mathrm{G}$ & $\mathrm{R}$ & $\mathrm{UC}$ & \\
\hline Simocephalus vetulus (Müller, 1776) & & & & UE1 & $\mathrm{G}$ & $\mathrm{R}$ & $\mathrm{UC}$ & \\
\hline \multicolumn{9}{|l|}{ Class Ostracoda } \\
\hline Cyprideis torosa (Jones, 1850) & & & LE7 & LE8 & $\mathrm{DF}$ & $\mathrm{UC}$ & & $\mathrm{C}$ \\
\hline Fabaeformiscandona fabaeformis (Fische & & UE2 & UE1,2 & UE1,4 & DF & $\mathrm{C}$ & $\mathrm{VC}$ & \\
\hline Herpetocypris brevicaudata (Kaufmann, 1900) & & UE3 & & & $\mathrm{DF}$ & $\mathrm{R}$ & UC & \\
\hline Herpetocypris sp. & & UE4 & & & $\mathrm{DF}$ & $\mathrm{R}$ & $\mathrm{UC}$ & \\
\hline \multicolumn{9}{|l|}{ Class Copepoda } \\
\hline Acanthocyclops latipes (Lowndes, 1927) & & & UE1 & & SF & $\mathrm{R}$ & $\mathrm{UC}$ & \\
\hline Canuella furcigera Sars, 1903 & & & LE7 & & $\mathrm{SF}$ & $\mathrm{R}$ & & UC \\
\hline Centropages chierchae Giesbrecht, 1889 & & & LE6 & & $\mathrm{SF}$ & $\mathrm{R}$ & & $\mathrm{UC}$ \\
\hline Cyclops sp. & & & & UE1,3 & $\mathrm{SF}$ & $\mathrm{UC}$ & $\mathrm{C}$ & \\
\hline Eucyclops serrulatus (Fischer, 1851) & & & UE1 & & SF & $\mathrm{R}$ & $\mathrm{UC}$ & \\
\hline Macrocyclops albidus (Jurine, 1820) & & UE1,2 & UE1 & UE1 & SF & $\mathrm{UC}$ & $\mathrm{C}$ & \\
\hline \multicolumn{9}{|l|}{ Class Malacostraca } \\
\hline Ampelisca brevicornis (Costa, 1853) & & & LE9 & & $\mathrm{SF}$ & $\mathrm{R}$ & & $\mathrm{UC}$ \\
\hline Ampelisca sp. & & & LE7 & & $\mathrm{SF}$ & $\mathrm{R}$ & & UC \\
\hline Ampelisca typica (Bate, 1856) & LE8,9 & LE9 & LE9 & & $\mathrm{SF}$ & $\mathrm{UC}$ & & $\mathrm{C}$ \\
\hline Apseudes latreillii (Milne-Edwards, 1828) & LE9 & LE8,9 & & & $\mathrm{DF}$ & $\mathrm{UC}$ & & $\mathrm{C}$ \\
\hline Bathyporeia sp. & & & & LE9 & $\mathrm{DF}$ & $\mathrm{R}$ & & UC \\
\hline Bodotria arenosa Goodsir, 1843 & & & & LE9 & DF & $\mathrm{R}$ & & UC \\
\hline Corophium orientale Schellenberg, 1928 & LE5,6,7,8,9 & UE4; LE5,6,9 & UE4; LE5,6 & UE3,4; LE5,6 & $\mathrm{DF}$ & $\mathrm{Ct}$ & $\mathrm{C}$ & $\mathrm{Ct}$ \\
\hline Corophium rotundirostre Stephensen, 1915 & & & LE7,8,9 & LE7, 8,9 & $\mathrm{DF}$ & $\mathrm{C}$ & & VC \\
\hline Cumopsis goodsir (Van Beneden, 1861) & & LE9 & & & DF & $\mathrm{R}$ & & $\mathrm{UC}$ \\
\hline Cyathura carinata (Krøyer, 1847) & LE7 & & LE7,8 & LE7,8 & $\mathrm{DF}$ & $\mathrm{UC}$ & & $\mathrm{C}$ \\
\hline Decapoda indet. & LE9 & & & LE7,9 & $\mathrm{O}$ & $\mathrm{UC}$ & & $\mathrm{C}$ \\
\hline Diastylis sp. & & LE8 & LE8 & LE6,7,8 & $\mathrm{DF}$ & UC & & $\mathrm{C}$ \\
\hline Echinogammarus longisetosus Pinkster, 1973 & UE1,3,4 & UE4 & UE2 & UE2 & $\mathrm{O}$ & $\mathrm{C}$ & $\mathrm{Ct}$ & \\
\hline Gammarus aequicauda (Martyinov, 1931) & & & & LE8 & $\mathrm{O}$ & $\mathrm{R}$ & & $\mathrm{UC}$ \\
\hline Iphinoe sp. & LE9 & LE9 & & LE7,8 & $\mathrm{DF}$ & $\mathrm{UC}$ & & UC \\
\hline Lembos sp. & & & & & $\mathrm{DF}$ & $\mathrm{R}$ & & UC \\
\hline Lembos spiniven & & & & LE7 & $\mathrm{DF}$ & $\mathrm{R}$ & & UC \\
\hline Leptocheirus pilosus Zaddach, 1844 & LE9 & & LE7 & LE8 & $\mathrm{SF}$ & $\mathrm{C}$ & & $\mathrm{VC}$ \\
\hline Leucothoe inci & LE9 & & LE7,8 & LE7,8 & $\mathrm{O}$ & $\mathrm{C}$ & & $\mathrm{VC}$ \\
\hline Liocarcinus corrugatus (Pennant, 1777) & & & LE9 & & $\mathrm{O}$ & $\mathrm{R}$ & & UC \\
\hline Medorippe lanata (Linnaeus, 1767) & & & LE9 & & $\mathrm{O}$ & $\mathrm{R}$ & & UC \\
\hline Micr & & LE9 & & & $\mathrm{O}$ & $\mathrm{R}$ & & UC \\
\hline Monoculodes acutipes Ledoyer, 1983 & LE9 & & LE8 & LE6,7,8,9 & $\mathrm{O}$ & $\mathrm{C}$ & & $\mathrm{Ct}$ \\
\hline Pariambus typicus (Kroyer, 1844) & & LE8 & LE8,9 & LE6,7,8 & $\mathrm{O}$ & $\mathrm{C}$ & & $\mathrm{Ct}$ \\
\hline Perioculodes longimanus (Bate \& Westwood, 1868) & & & & LE7,8 & $\mathrm{DF}$ & $\mathrm{UC}$ & & $\mathrm{C}$ \\
\hline Phtisica marina Slabber, 1769 & & & LE6,7 & LE7,8 & $\mathrm{O}$ & $\mathrm{C}$ & & $\mathrm{VC}$ \\
\hline Praunus flexиos & LE9 & & & & SF & $\mathrm{R}$ & & UC \\
\hline Pseudocuma longicorne (Bate, 1858) & LE8 & LE9 & & & $\mathrm{DF}$ & $\mathrm{UC}$ & & $\mathrm{C}$ \\
\hline Sphaeroma serratu & & & & LE8 & $\mathrm{O}$ & $\mathrm{R}$ & & $\mathrm{UC}$ \\
\hline Synchelidium haplocheles (Grube, 1864) & LE7 & UE4 & & & $\mathrm{DF}$ & $\mathrm{UC}$ & $\mathrm{UC}$ & $\mathrm{UC}$ \\
\hline Synchelidium sp. & LE8 & & & & $\mathrm{DF}$ & $\mathrm{R}$ & & UC \\
\hline Upogebia pusilla (Petagna, 1792) & LE9 & & & & $\mathrm{SF}$ & $\mathrm{R}$ & & UC \\
\hline Upogebia sp. & & LE9 & & & $\mathrm{SF}$ & $\mathrm{R}$ & & UC \\
\hline \multicolumn{9}{|l|}{ Class Euentomata } \\
\hline Baetis fuscatus (Linnaeus, 1761) & UE2 & UE2,3 & & UE2 & DF & $\mathrm{UC}$ & $\mathrm{C}$ & \\
\hline Baetis pavidus Grandi, 1949 & LE7 & & LE6,7 & & $\mathrm{DF}$ & $\mathrm{UC}$ & & $\mathrm{C}$ \\
\hline Caenis luctuosa (Burmeister, 1839) & UE1,2,3 & UE1,2 & UE1,2 & UE1,2 & DF & $\mathrm{C}$ & $\mathrm{VC}$ & \\
\hline
\end{tabular}


APPENDIX 1 (cont.). - List of the identified taxa that were found at all the stations over the entire study period. The stations where each taxon was found are also listed. See Figure 1 for sampling station codes; FG, feeding guild (see Table 2 for feeding guild codes); CI, Constancy index; $\mathrm{Ct}$, constant; $\mathrm{VC}$, very common; C, common; UC, uncommon; R, rare.

\begin{tabular}{|c|c|c|c|c|c|c|c|c|}
\hline Taxa & Summer & Autumn & Winter & Spring & FG & $\mathrm{CI}$ & $\begin{array}{l}\text { CI } \\
\text { UE }\end{array}$ & $\begin{array}{l}\text { CI } \\
\text { LE }\end{array}$ \\
\hline Ceraclea dissimilis (Stephens, 1836) & & & & UE2 & DF & $\mathrm{R}$ & $\mathrm{UC}$ & \\
\hline Ceraclea sobradieli (Navás, 1917) & UE2 & & & UE2 & $\mathrm{DF}$ & $\mathrm{R}$ & UC & \\
\hline Chironomus sp. & LE7,8 & UE4 & UE1 & UE1,3; LE6 & $\mathrm{DF}$ & $\mathrm{VC}$ & $\mathrm{VC}$ & $\mathrm{VC}$ \\
\hline Choroterpes picteti (Eaton, 1871) & UE2 & & & & DF & $\mathrm{R}$ & UC & \\
\hline Coenagrion pulchellum (Van der Linden, 1825) & & & & UE1 & $\operatorname{Pr}$ & $\mathrm{R}$ & UC & \\
\hline Coenagrionidae indet. & & UE1 & UE1 & & $\operatorname{Pr}$ & $\mathrm{R}$ & UC & \\
\hline Drypos sp. & & UE1 & UE1 & & $\mathrm{G}$ & $\mathrm{R}$ & UC & \\
\hline Ecnomus tenellus (Rambur, 1842) & UE2 & $\mathrm{UE} 1,2$ & UE2 & UE2 & $\mathrm{O}$ & $\mathrm{UC}$ & $\mathrm{C}$ & \\
\hline Ephoron virgo (Olivier, 1791) & UE1,2,3,4 & & & UE2 & $\mathrm{SF}$ & $\mathrm{C}$ & $\mathrm{Ct}$ & \\
\hline Hydropsyche exocellata Duföur, 1841 & UE2 & UE2 & LE5 & UE2 & SF & $\mathrm{UC}$ & UC & $\mathrm{UC}$ \\
\hline Hydroptila sp. & UE2 & UE2 & & UE2 & G & $\mathrm{R}$ & UC & \\
\hline Mystacides azurea (Linnaeus, 1761) & UE2 & & & & $\mathrm{DF}$ & $\mathrm{R}$ & UC & \\
\hline Orthotrichia angustella (McLachlan, 1865) & & & UE2 & & $\mathrm{G}$ & $\mathrm{R}$ & UC & \\
\hline Pseudocloeon atrebatinus Eaton, 1870 & UE2 & UE2 & UE2 & & $\mathrm{DF}$ & $\mathrm{R}$ & $\mathrm{UC}$ & \\
\hline Psychomyia pusilla (Fabricius, 1781) & & & & UE2 & DF & $\mathrm{R}$ & UC & \\
\hline Sf. Orthocladiinae indet. & UE1,2; LE7 & $\mathrm{UE} 1,2,4$ & UE1,2,4; LE5,6,7 & UE1,2; LE5,7,8 & DF & $\mathrm{Ct}$ & $\mathrm{VC}$ & $\mathrm{Ct}$ \\
\hline Sf. Tanypodinae indet. & UE1 & $\mathrm{UE} 1,2,3,4$ & UE1 & UE1 $2,3,4$ & $\operatorname{Pr}$ & $\mathrm{C}$ & $\mathrm{Ct}$ & \\
\hline Simulium erithrocephalum (De Geer, 1776) & UE2 & & UE2 & & $\mathrm{SF}$ & $\mathrm{R}$ & UC & \\
\hline Tr. Chironomini indet. & UE1 & UE4 & UE2 & UE2 & $\mathrm{DF}$ & $\mathrm{C}$ & $\mathrm{VC}$ & \\
\hline Tr. Tanytarsini indet. & $\mathrm{UE} 1,2$ & UE2,3 & $\mathrm{UE} 1,2$ & $\mathrm{UE} 1,2,3$ & $\mathrm{DF}$ & $\mathrm{C}$ & $\mathrm{VC}$ & \\
\hline Trithemis annulata (Palisot de Beauvois, 1807) & & UE1 & & & $\operatorname{Pr}$ & $\mathrm{R}$ & UC & \\
\hline \multicolumn{9}{|l|}{ PHYLUM PHORONIDA } \\
\hline \multicolumn{9}{|l|}{ Class Phoronida } \\
\hline Phoronis ovalis Wright, 1856 & & & & LE6 & $\mathrm{SF}$ & $\mathrm{R}$ & & $\mathrm{UC}$ \\
\hline Phoronis psammophila Cori, 1889 & & LE5,7,8,9 & LE6,7,8 & LE6,7,8 & $\mathrm{SF}$ & $\mathrm{VC}$ & & $\mathrm{Ct}$ \\
\hline \multicolumn{9}{|l|}{ PHYLUM ECHINODERMATA } \\
\hline \multicolumn{9}{|l|}{ Class Holothuroidea } \\
\hline Thyone sp. & & & LE7 & LE7,8 & $\mathrm{DF}$ & $\mathrm{UC}$ & & $\mathrm{C}$ \\
\hline \multicolumn{9}{|l|}{ Class Ophiuroidea } \\
\hline Amphipholis squamata (Delle Chiaje, 1828) & LE9 & LE9 & LE7,8 & LE8 & $\mathrm{DF}$ & $\mathrm{C}$ & & $\mathrm{VC}$ \\
\hline Amphiura chiajei Forbes, 1843 & & & LE9 & LE7 & DF & $\mathrm{UC}$ & & $\mathrm{C}$ \\
\hline \multicolumn{9}{|l|}{ Class Echinoidea } \\
\hline Fibulariidae indet. & LE9 & & & & $\mathrm{DF}$ & $\mathrm{R}$ & & $\mathrm{UC}$ \\
\hline Echinocardium sp. & & LE9 & & & $\mathrm{DF}$ & $\mathrm{R}$ & & $\mathrm{UC}$ \\
\hline
\end{tabular}

